\title{
Vegetation dynamics and mesophication in response to conifer encroachment within an ultramafic system
}

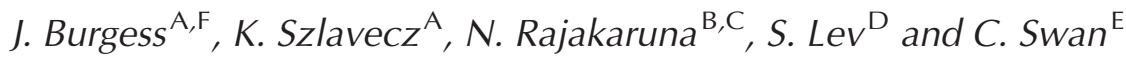 \\ A Department of Earth and Planetary Sciences, Johns Hopkins University, Baltimore, MD 21218, USA. \\ ${ }^{\mathrm{B} C o l l e g e}$ of the Atlantic, 105 Eden Street, Bar Harbor, ME 04609, USA. \\ CUnit for Environmental Sciences and Management, North-West University, Private Bag X6001, \\ Potchefstroom, 2520, South Africa. \\ DUrban Environmental Biogeochemistry Laboratory, Towson University, 8000 York Rd., Towson, \\ MD 21252-0001, USA. \\ EDepartment of Geography \& Environmental Systems, University of Maryland, Baltimore County, \\ Baltimore, MD 21250, USA. \\ ${ }^{\mathrm{F} C}$ Corresponding author. Email: jerry.burgess@jhu.edu
}

\begin{abstract}
The biological, ecological, and evolutionary significance of serpentine habitats has long been recognised. We used an integrated physiochemical dataset combining plot spatial data with temporal data from tree cores to evaluate changes in soils and vegetation. Data suggest that this unique habitat is undergoing a transition, endangering local biodiversity and endemic plant species. The objective of this work was to analyse the vegetation dynamics of a xeric serpentine savanna located in the Mid-Atlantic, USA. We employed vegetation surveys of 321015 m quadrats to obtain woody species composition, density, basal area, and developed a spatial physiochemical dataset of substrate geochemistry to independently summarise the data using regression and ordination techniques. This information was interpreted alongside historical, dendrochronologic and soil stable carbon isotopic data to evaluate successional dynamics. Comparisons among geologic, pedologic and vegetation environmental drivers indicated broad correlations across an environmental gradient, corresponding to a grassland to forest transition. The woodland communities appear to be part of a complex soil moisture and chemistry gradient that affects the extent, density, basal area and species composition of these communities. Over the gradient, there is an increase in $\alpha$ diversity, a decrease in the density of xeric and invasive species, and an increase in stem density of more mesic species. Dendrochronology suggests poor recruitment of xeric species and concomitant increase in more mesic species. The data indicated that former $\mathrm{C}_{4}$-dominated grasslands were initially invaded by conifers and are now experiencing mesophication, with growing dominance by Acer, Nyssa and more mesic Quercus and Fagus species.
\end{abstract}

Additional keywords: edaphic, plant-soil relations, serpentine, succession.

\section{Introduction}

Vegetation dynamics associated with environmental gradients are strongly linked to the underlying abiotic drivers such as the heterogeneity of resources (Grime 1979; Huston 1979; Tilman 1984, 1987; Robertson et al. 1988; Williams and Houseman 2013). In areas with strong abiotic influence, the trait-environment theory is expected to predominate as the overall species pool is filtered on the basis of ecologically relevant life-history traits (Keddy 1992; Díaz et al. 1998; Lawton 1999; Butaye et al. 2002; FernandezGoing et al. 2013).

Research over the past century on the relative strengths of the individualistic, organismal and integrated community concepts has provided little consensus on the mechanisms shaping community dynamics (Clements 1916; Gleason 1926; Lortie et al. 2004; Götzenberger et al. 2012). Community assembly in early succession depends on the inherent size of the species pool and the dispersal potential of the organisms, whereas the establishment of vascular plants in early succession stages is partly limited by tolerance to drought stress (Weiher and Keddy 1999; Jones and del Moral 2009). However, disturbance regimes are also important in the creation and maintenance of vegetation mosaics as well as controlling species dynamics (White 1979; Pickett and White 1985).

One landscape that demonstrates the tight coupling of abiotic drivers among plants, soils, and lithology is the serpentinite or ultramafic terrain. In the Appalachian Piedmont, ultramafic rocks occur in a variety of geologic settings and often form restrictive habitats with unusual vegetation chiefly because of certain 
edaphic factors such as low nutrient content, high metal concentrations and shallow soils (Rajakaruna et al. 2009). Such communities are of interest because they harbor endemic species and unique community types, and serve as model systems to study insular communities (Harrison and Rajakaruna 2011). These edaphic systems often exist as isolated units with distinct early successional communities that are embedded in the regional landscape. Frequent fire or herbivory is often proffered as necessary to maintain soil conditions and the unique native grassland communities (Latham 1993; Tyndall 1992, 2005; Arabas 2000). During the past century, many grass-dominated ecosystems around the world have been affected by the spread of woody plants (Archer et al. 1995; Van Auken 2000, 2009). In the absence of frequent disturbance, the once expansive xerophytic grasslands and savannas on ultramafic substrate may succumb to secondary succession and become forests or woodlands; however, remnants of these areas are still present (Tyndall and Farr 1989, 1990; Smith and Barnes 2008; Burgess et al. 2009; Noss 2013). The remaining grasslands exhibit 'prairie'-type compositions, with shortgrass mixed with tallgrass, and were likely more expansive formerly than today (Marye 1955a, 1955b, 1955c; Tyndall 1992). Tyndall (1992) and Tyndall and Farr $(1989,1990)$ have documented the expansion of conifers in serpentinite grasslands, yet the extent and dynamics of the serpentinite closed-canopy forests or woodlands has not been investigated. These serpentinite woodland regions of the MidAtlantic Piedmont of eastern North America are the focus of this research.

In eastern North America, a rich history of vegetation change has resulted in textbook models of succession based on abandoned agricultural fields that follows the general trend of annual herbs, followed by grasses and perennial herbs, followed by woody species colonisation and eventual dominance (Oosting 1942; Keever 1950; Bazzaz 1968; Inouye et al. 1987). However, edaphic succession does not correspond to this textbook model. Edaphic features, such as those arising from ultramafic parent material, can heavily influence the spatial-temporal distribution of succession (Curtis 1959; Whittaker 1960; Callaway and Davis 1993; Zavala et al. 2000; Wright and Fridley 2010). Areas underlain by serpentinite and other ultramafic rock types are limited in calcium and potassium and high in toxic elements, including magnesium, chromium and nickel, typically resulting in harsh soils and sparse plant communities (e.g. Kruckeberg 1984; Proctor and Nagy 1992; Alexander et al. 2007; Rajakaruna and Boyd 2009; Harris and Rajakaruna 2009).

Serpentinite outcrops in the Appalachians form characteristic ecosystems termed grasslands, barrens, balds and savannas. Those of the Mid-Atlantic are characterised by savanna or grassland if maintained by periodic disturbance; however, forests cover much of the Piedmont upland region underlain by ultramafic bedrock as well. Within this landscape, there are patchily arranged xerophytic enclaves surrounded by more mesophytic vegetation. The mosaics are prairie-like openings and pine scrub or greenbrier thickets grading to mixed pine-deciduous woodlands and oak-dominated forests. Work by Tyndall (2005) and Cumming and Kelly (2007) suggested that relict grasslands and pine savanna soils have altered abiotic properties, lowered herbaceous diversity and shifted fungal communities as a result of recent conifer expansion. However
Barton and Wallenstein (1997) found that soils invaded by pine actually had similar or lower nutrient and organic matter contents than early successional savanna and exhibited no difference in calcium : magnesium ratios, a critical ultramafic soil indicator.

We investigated how vegetation dynamics relate to geoecological gradients based on soil properties and whether the encroachment of woody species threatens the biological integrity of a globally rare ecosystem by altering the successional trajectory (inter alia as regards the woody species richness, composition and structure) in a traditionally xeric environment. The specific objectives of this research were to (1) examine the dynamics of woodlands supported by ultramafic soils, (2) reconstruct a partial vegetation history and (3) assess the impact of recent woody encroachment on soil properties and successional trajectories. We hypothesised that changes in vegetation dynamics from grassland to woodland would not result in a local edaphic climax nor will the anomalous flora continue to persist in discrete patches. We expected that this edaphic succession would be accompanied by an increase in soil organic matter and calcium $(\mathrm{Ca})$ : magnesium $(\mathrm{Mg})$ ratios, a decrease in $\mathrm{pH}$ in a soil profile, and a loss of the traditional serpentine grassland signature accompanied by species redistribution. Ultimately, this mesophication and homogenisation will result in a woodland community indistinguishable from typical Piedmont soil substrates.

To achieve these goals, we integrated natural history records, tree-ring data, woody species community data, stable isotope data from soil organic matter and a suite of soil physio-chemical properties. Geologic, pedologic and vegetation property comparisons were evaluated using a chronosequence approach to study serpentine succession that makes critical assumptions such as each site in the sequence formed from the same substrate, differs only in age, and that each site has traced the same history in both its abiotic and biotic components (Huggett 1998; Johnson and Miyanishi 2008). Understanding community assembly of such communities helps explain contemporary vegetation dynamics at multiple scales, and thus manage them for future conditions (Foster et al. 2003).

\section{Materials and methods}

\section{Site description and background}

The study was conducted in a Mid-Atlantic temperate Piedmont area (Fig. 1). The site consists of privately owned and cooperatively protected land (Camp Moshava), with a xeric to mesic upland supporting a >105-ha oak-conifer woodland located near Cherry Hill, Maryland, USA (39 64' N, $7636^{\prime} \mathrm{W}$ ). The mean annual temperature and rainfall are $12 \mathrm{C}$ and $1133 \mathrm{~mm}$, respectively (Maryland State Climatologist Office 2014). Topographic elevation ranges from 90 to $145 \mathrm{~m}$ above mean sea level.

The Cherry Hill field site (CHS) lies within the largest mafic complex in the Appalachians, known as the Baltimore Ultramafic-Mafic Complex (BMC). Ultramafic components of the BMC contain a basal unit of serpentinised peridotite with relict websterite and dunite. These units are likely to represent parts of an ophiolitic island arc or a supra-subduction zone complex that was obducted onto Laurentia during the closure of Iapetus during the Taconic orogeny at $\sim 455$ million years ago (Muller 
et al. 1989). The CHS is more enigmatic, lying within the Boulder Gneiss metasedimentary (diamictite) unit and bounded to the north by metagraywacke (Fig. 1) and is likely to represent a fragmented sliver of a once larger complex. Vegetation atop the study area varies from mature forests to savanna-like areas with open-grown trees, and diverse grassland with a wide variety of grasses and forbs.

A forest encloses the remnant grasslands of the study area and exhibits a transitional ecotone, ranging from 10 to $15 \mathrm{~m}$ (Fig. 2). The dominant trees within the forest are oak species (Quercus spp.), whereas at the transition, eastern red cedar (Juniperus virginiana L) and Virginia pine (Pinus virginiana Mill) are also important. On the basis of historical records (e.g. diaries

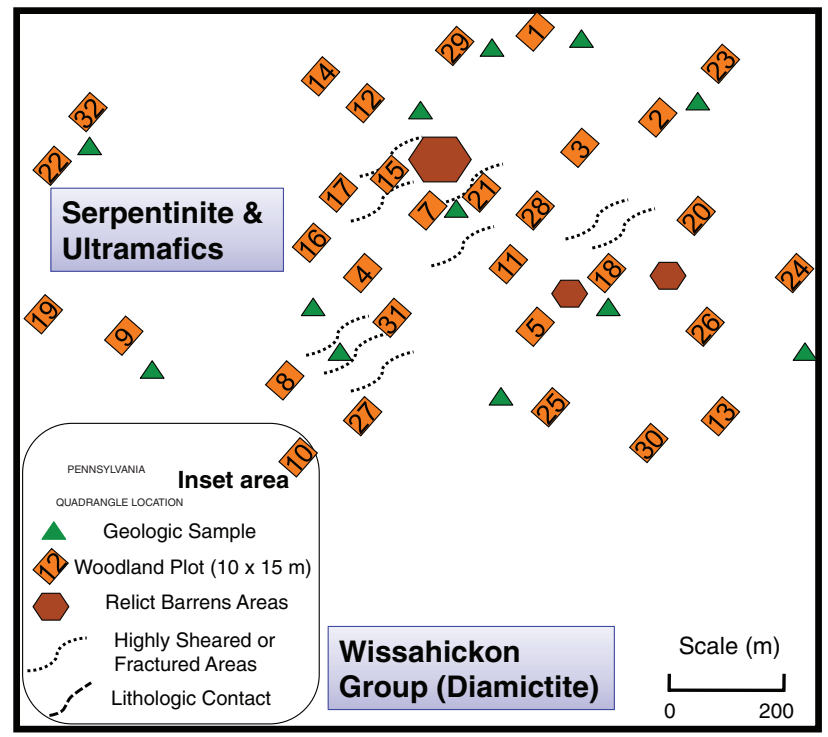

Fig. 1. Topographic map of the sampling area in near Maryland Pennsylvania boundary, USA. Note that plot sizes are not to scale. and mining and forestry reports such as found in Jefferis 1880; Williams and Darton 1892; Abbe 1898), aerial photographs (Maintained at the Maryland Geological Survey and Harford County Soil Survey Libraries) and interviews, this study area has not been farmed or burned during the past century. Shortly after a grassland or savanna survey by Tyndall and Farr (1989), conifers were eliminated in the grassland in a restoration attempt. In the savanna and grassland patches, disjunct populations of $\mathrm{C}_{4}$ bunchgrass species, including little bluestem (Schizachyrium scoparium (Michx.) Nash var. scoparium), big bluestem (Andropogon gerardii Vitman), arrowfeather threeawn (Aristida purpurascens Poir) and prairie dropseed (Sporobolus heterolepis A.Gray) are interspersed with a variety of herbaceous $\mathrm{C}_{3}$ species such as Carex umbellata Willd. (parasol sedge) and Smilax spp. (greenbrier).

\section{Abiotic characteristics}

We carried out detailed geologic mapping to assess how vegetation characteristics were influenced by geologic substrate. After geologic mapping, 32 quadrats (see Fig. 1) were established using stratified random sampling to encompass the variety of environmental conditions in the area. Quadrats (10 $15 \mathrm{~m})$ were oriented up and down slope to cover distinct changes in environmental gradients and community types. Near the centre of each plot, latitude, longitude, elevation, slope and aspect were determined and recorded with a GPS device.

During the mapping phase, representative rock samples of the freshest serpentinites $(n=12)$ were systematically selected for petrographic analysis from samples collected $(n=34)$ during field mapping. Both major and trace elemental whole-rock analyses were conducted using X-ray fluorescence (XRF). Major elements were determined on glass beads fused from ignited powders to which $\mathrm{Li}_{2} \mathrm{~B}_{4} \mathrm{O}_{7}$ was added $(1: 5)$, in a platinum crucible at $1150 \mathrm{C}$. Trace elements were analysed on pressed powder pellets by the same instrument, a Bruker AXS S4 Explorer, following the procedures outlined by Potts (1987).

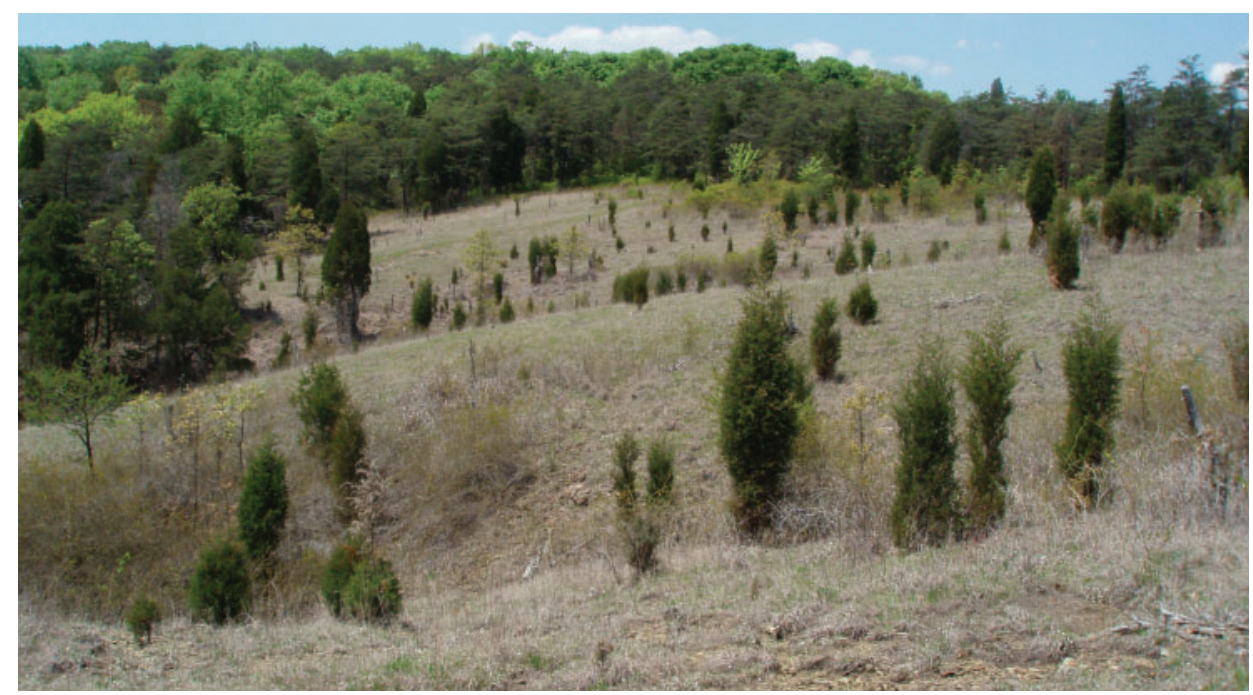

Fig. 2. Field photograph showing insular relict barrens and grassland being encroached upon by eastern red cedar (Juniperus virginiana) with surrounding mixed-oak (Quercus) woodlands. Photo by J. Burgess. 
Counting statistics errors are $0.1 \%$ for major elements and average detection limits are $50-100 \mathrm{mg} \mathrm{kg}^{-1}$ for major oxides, and 5-10 ppm for chromium (Cr), nickel (Ni), titanium (Ti), iron $(\mathrm{Fe})$, manganese $(\mathrm{Mn}), \mathrm{Ca}$, potassium $(\mathrm{K})$ and phosphorus (P). All XRF samples were quantified using a matrix matched set of USGS- and NIST-certified soil standards. At least one duplicate, one replicate and one certified reference sample (SRM 2709, San Joachin Soil) was run with every 10 samples analysed, to monitor for external and internal reproducibility. Loss on ignition (LOI) for samples is measured by igniting rock powders in alumina crucibles to $1200 \mathrm{C}$ for $10 \mathrm{~min}$ in a muffle furnace.

Soil characteristics evaluated for each plot or quadrat included bulk density, soil depth, $\mathrm{pH}$, soil organic matter content, major and trace element analysis, carbon $(\mathrm{C})$ : nitrogen $(\mathrm{N})$, and isotopic and textural analysis. Surface soil epipedons were evaluated for bulk density $\left(\mathrm{g} \mathrm{cm}^{-3}\right)$. At each location, we composited five soil cores (corners plus centre) that were taken with a 5-cm-diameter soil corer. Soil cores were sectioned into 0-5, 5-10, 10-15 (and at some sites 5-15) $\mathrm{cm}$ increments, dried at $40 \mathrm{C}$ to a constant weight and then calculated as dry weight of sample per unit of soil volume with roots removed. Soil parameter values were averaged to provide a representative value for each $150-\mathrm{m}^{2}$ plot.

Forest soil depth (depth to obstruction) was measured with a push soil probe at five random locations in each plot. For soil moisture or soil depth comparisons from savanna into forested areas, four transects (35-68 m long) were established in April 2011. Our rationale was that distance from bedrock would represent a proxy for time, and points along these transects would generally represent soil chronosequence (Jenny 1941, 1980). Because of the inherent low moisture values of serpentine soils, measurements were made during the week after a 5-mm or greater rainfall event. Soil moisture values at 0-6-cm depth were measured with a ThetaProbe ${ }^{\circledR}$ soil moisture sensor (Dynamax Inc., Houston, TX, USA), and soil depths with a push probe (internal diameter $=4.7 \mathrm{~cm}$ ) every $1 \mathrm{~m}$.

Soil samples for chemical analysis were air-dried and passed through a USA Standard No. 10 sieve. Bedrock thin-sections occasionally contain carbonate (calcite and magnesite), therefore, initial soils were evaluated for carbonate by an acid (1 M hydrochloric) test. The $\mathrm{HCl}$ test showed that the soil samples did not contain carbonates; therefore, total $\mathrm{C}$ in the soil represents organic C only.

Moist soil colour was determined in the field using Munsell colour charts (Munsell Color, Grand Rapids, MI, USA). Samples were combined, mixed, and split to give two samples of $200-400 \mathrm{~g}$ that were lightly crushed and sieved to $2 \mathrm{~mm}$ and sampled for textural analysis (sieve followed hydrometer method) (Bouyoucos 1936). Soil pH was measured with a $20 \mathrm{~g}$ in $20 \mathrm{~mL}$ soil-water slurry by using a glass electrode. The remainder was oven-dried at $30 \mathrm{C}$ and powdered using an agate centrifugal ball mill. A powdered subset was subsequently used for XRF and $\mathrm{C}: \mathrm{N}$ analyses. Total $\mathrm{N}$ and $\mathrm{C}$ were measured with an automated Perkin-Elmer 2400 Series II CHN analyser (Perkin-Elmer, Cornell Labs, Ithaca, NY, USA). Soil organic matter content was estimated as loss on ignition (LOI) at $550 \mathrm{C}$ for $3 \mathrm{~h}$. Total $\mathrm{C}, \mathrm{N}$ and isotopic analysis were conducted at the stable isotope facilities at either the University of California at Davis, CA, or Cornell Laboratories, Ithaca, NY, using an elemental analyser interfaced with continuous-flow isotope-ratio mass spectrometer. Values reported are typically means with the associated standard error. All the values were reported as per mil $(\% o)$ relative to the international standard Vienna Pee Dee Belemnite (V-PDB) and were calculated as

$$
\delta^{13} \mathrm{C}(\%)=\left(\frac{R_{\text {sample }} R_{\text {standard }}}{R_{\text {standard }}}\right) \quad 1000,
$$

where $\delta^{13} \mathrm{C}$ is the difference between ${ }^{13} \mathrm{C}:{ }^{12} \mathrm{C}$ ratio $(\mathrm{R})$ of the sample and that of the standard. Increase in the $\delta$ value reflects increases in the relative amount of the heavy isotope component or a reciprocal decrease in the light isotope component.

\section{Biotic characteristics}

To monitor the serpentine ecosystem-scale vegetation-boundary movement, we examined a time series of high-resolution images from Google Earth (1994-2013), along with aerial photography from 1937, 1952, 1971 and 1988, using the grid-square method. The more recent data serve to complement the work by Tyndall (1992) on the expansion of conifers into barrens areas. All woody plant species were recorded for each sampling plot. To identify plants, we followed the key by Brown and Brown (1984), with nomenclature clarification via the integrated taxonomic information system. Woody plants with diameter-at-breastheight $(\mathrm{DBH})$ of $>10 \mathrm{~cm}$ are referred to as trees, those with $\mathrm{DBH}$ of $<10 \mathrm{~cm}$ and $>2 \mathrm{~cm}$, or $2 \mathrm{~m}$ height, as saplings, and any woody species $<2$-cm DBH are grouped as seedlings or vines. For species where DBH is impractical (shrubs), stems were measured with a caliper near the root collar. Absolute and relative stem density and basal area were derived from these data.

Canopy cover was measured at each plot centre with a spherical densiometer. Plots were classified as savanna, woodland or forest on the basis of canopy cover, as follows: savanna $(0-25 \%$ canopy cover), woodland (26-60\% canopy cover) and forest ( $>60 \%$ canopy cover). Ground-layer percentage cover for soil, leaf litter and rock was estimated visually.

To assess vegetation change over time, historical records were combined with tree-core data $(n=163)$. One increment core was extracted for each tree species per plot when possible. Cores were taken at breast height, mounted and sanded following Stokes (1996) and Stokes and Smiley (1968). Because increment cores were collected at $1.37 \mathrm{~m}$ above the ground, we considered the ages obtained as the minimum age of trees at breast height. Repetitive coring was carried out to facilitate the interception of the pith. Missing rings in incomplete cores were estimated using diameter age-regression curves (Lorimer 1980). Ring counts were made using a stereomicroscope at 10-40 magnification. Each core sample was skeleton plotted to identify narrow rings (Speer 2010). The resulting age distribution was divided into date thresholds to record pulses or absence of regeneration as cohorts.

\section{Data analysis}

To quantify forest structure, the quadrats were characterised by basal area $\left(\mathrm{m}^{2} \mathrm{ha}^{-1}\right)$ and density $\left(\right.$ stems ha $\left.{ }^{-1}\right)$ of live specimens of the principal tree species. Tree species were grouped on the basis of habitat affinity (xeric/mesic) using the USDA silvics manual (Walters and Yawney 2004). Diversity indices were calculated 
for each plot and on pooled plot data, using the Shannon-Weaver index (Shannon and Weaver 1949) and the Simpson index (Simpson 1949) as measures of $\alpha$ diversity $(\alpha)$ along with estimators of total diversity using rarefaction and nonparametric approaches of Chao 1, Chao 2 and ACE (Chao 1984, 1987; Chazdon et al. 1998). The importance value (IV) is a measure of relative abundance and was calculated as the average of relative density and dominance.

The Kolmogorov-Smirnov test statistic was used to assess normality of the soil variables. Those that failed the normality test were transformed to normal or near-normal distribution. Percentage measurements (soil particle analysis, abundance, $\mathrm{C}$, $\mathrm{N}$, cover, XRF whole-rock oxide weight) were arcsine transformed; soil elemental data were $\log _{e}$ transformed from ppm or ppb concentrations; slope and soil depth were naturallog transformed; and bulk density was square-root transformed.

Site microclimate variability was compared using geographic coordinates (latitude and longitude), inclination and aspect for each plot to calculate the heat load and the potential annual direct incident radiation by applying the third equation from McCune and Keon (2002). The effects of topographic (slope, inclination, annual direct incident radiation and heat load) and soil variables (elemental analysis in addition to $\mathrm{pH}$, soil organic $\mathrm{C}$, total $\mathrm{N}$, $\mathrm{C}: \mathrm{N}$, depth, texture, and $\delta^{13} \mathrm{C}$ values) on species were examined using principal components analysis (PCA) to explore the main factors and generate hypotheses as to the reciprocal effects of these properties on vegetation. Redundancy analysis (RDA) ordination as constrained by the environmental variables was performed to identify the main floristic gradients (basal area, density, percentage xeric species) and the edaphic and topographic factors explaining those trends. Two-way ANOVA was used to test for the differences in soil $\delta^{13} \mathrm{C}, \mathrm{C}, \mathrm{N}$ and $\mathrm{C}: \mathrm{N}$ with respect to vegetation (grassland, forest) and soil depth. ANOVAs were followed by Tukey's HSD (chosen because of uneven number of replicates) multiple pairwise comparison to relate differences in elemental content and depth.

Differences in site woody-species composition were investigated by calculating the pairwise ecological distance for the entire species matrix. The Mantel test was used to determine whether site similarity in the tree community was related to site environmental variables. Multiple linear regression analysis was used to identify site factors that had a significant effect on species abundance. The eight highest-ranked species on the basis of IV were evaluated in terms of their abundances as response variables, and soil and topographic data were used as explanatory variables. Ordination using direct (RDA) and indirect (PCA) gradient analysis was employed to extract variation in the underlying structure of the vegetation data as it relates to environmental variables (Ludwig and Reynolds 1988). PCA was performed to find the main factors determining the reciprocal effects of soil and vegetation.

The Bray-Curtis distance, with raw abundances, was used to determine the degree of vegetation dissimilarity, an aspect of $\beta$ ( $\beta$ ) diversity between sites and vegetation types (woodland and forest) based on presence/absence. We used a Mantel test (McCune and Grace 2002) to compare the matrix of geographic distances between plots with the matrix of ecological distance. Potential relationships between abiotic variables and diversity variables (floristic similarity, evenness and Simpson's diversity) were explored. Tree-species compositions of early successional woodland and more mature forest designations based on percentage canopy were compared using non-parametric analysis of similarities (ANOSIM), based on the hypotheses of no difference between stages.

Gamma $(\gamma)$ or serpentine landscape-area diversity was estimated using all 32 plots to identify species richness at the landscape scale by constructing a rarefaction curve for all samples and all species in the dataset.

For all statistical tests, significance was determined at the $\alpha=0.05$ level, other $P$-values were reported if $<0.1$. The method for evaluating the Mantel-test statistic was the $t$-distribution (Mantel 1967) and the standardised Mantel statistic ( $r$ ) as a measure of effect size (McCune and Grace 2002).

All data were analysed using the statistical computing environment $\mathrm{R}$ (v. 3.1.1) and the BiodiversityR package (Kindt and Coe 2005). ANOSIM, Mantel and other tests were performed with $n=1000$ permutations. Reported errors are standard errors (s.e.), unless indicated otherwise.

\section{Results}

\section{Abiotic substrate and soil composition}

Mean whole-rock major-element values were typical of altered ultramafic rocks (Table 1). Calcium and aluminium (Al) contents were low, reflecting disappearance of the calcic pyroxene by serpentinisation. Only samples where clinopyroxene was detected showed an increase in $\mathrm{Ca}$. Samples with elevated $\mathrm{Al}$ are generally accompanied by the presence of chlorite in the rocks. As is typical of ultramafics, the immobile refractory elements $\mathrm{Cr}$ and $\mathrm{Ni}$ were elevated. Ternary diagrams depicting the measured whole-rock geochemistry of the samples illustrated relative compositional variations in the system $\mathrm{MgO}-\mathrm{SiO}_{2}-\mathrm{H}_{2} \mathrm{O}$

Table 1. Summary of the whole-rock geochemistry parameters for serpentinite samples obtained from X-ray fluorescence (XRF) analysis Serpentinite water content based on loss on ignition (LOI); $12.4 \quad 0.3$ weight $\%$. Al, aluminium; Ca, calcium; $\mathrm{Cr}$, chromium; Fe, iron; K, potassium; Mg, magnesium; Na, sodium; Ni, nickel; $\mathrm{Si}$, silicon; Ti, titanium; V, vanadium; Zn, zinc

\begin{tabular}{|c|c|c|c|c|c|c|c|c|c|c|c|c|}
\hline \multirow{2}{*}{$\begin{array}{l}\text { Lithology } \\
\text { Serpentinite, } n=12\end{array}$} & \multicolumn{8}{|c|}{ Major element geochemistry (weight \%) } & \multicolumn{4}{|c|}{ Trace elements $\left(\mathrm{mg} \mathrm{kg}^{-1}\right)$} \\
\hline & $\mathrm{Si}$ & $\mathrm{Al}$ & $\mathrm{Fe}$ & $\mathrm{Mg}$ & $\mathrm{Ca}$ & $\mathrm{Na}$ & $\mathrm{K}$ & $\mathrm{Ti}$ & $\mathrm{Cr}$ & $\mathrm{Ni}$ & V & $\mathrm{Zn}$ \\
\hline Mean & 41.29 & 0.31 & 9.54 & 36.69 & 0.42 & 0.00 & 0.07 & 0.02 & 2837.99 & 2319.68 & 11.89 & 43.85 \\
\hline s.e. & 0.88 & 0.15 & 0.78 & 0.70 & 0.22 & 0.00 & 0.02 & 0.00 & 286.51 & 157.16 & 3.34 & 5.94 \\
\hline Soils $(0-5 \mathrm{~cm}), n=32$ & 35.13 & 0.91 & 6.57 & 6.25 & 0.24 & 0.15 & 0.70 & 0.48 & 2526.51 & 1157.44 & 96.78 & 107.05 \\
\hline s.e. & 1.32 & 0.19 & 0.40 & 0.60 & 0.06 & 0.03 & 0.05 & 0.03 & 276.41 & 130.40 & 6.42 & 4.63 \\
\hline Soils $(5-15 \mathrm{~cm}), n=48$ & 37.99 & 1.05 & 7.44 & 7.62 & 0.15 & 0.15 & 0.69 & 0.46 & 2347.90 & 1244.34 & 97.25 & 84.26 \\
\hline s.e. & 1.06 & 0.20 & 0.36 & 0.60 & 0.04 & 0.02 & 0.05 & 0.03 & 207.26 & 110.24 & 5.54 & 3.11 \\
\hline
\end{tabular}


(Fig. 3). Concentrations of soil macronutrients C, N, P and K were not related to ultramafic parent material.

Soil depths varied from $10.5 \mathrm{~cm}$ to $52 \mathrm{~cm}$, with variable texture (mean of $13.4 \%$ gravel) across the sites. Soil colours ranged from dark brown (7.5YR 3/2) to grey (7.5YR 6/1) in the upper $1-5 \mathrm{~cm}$ of the soil profile to yellow-brown (10YR 5/6) and red-brown (2.5YR 4/4) with depth. Talcose serpentinites yielded more yellow (10YR Hues) varieties. The mean and standard error of soils collected from the 32 plots recorded a narrow range of

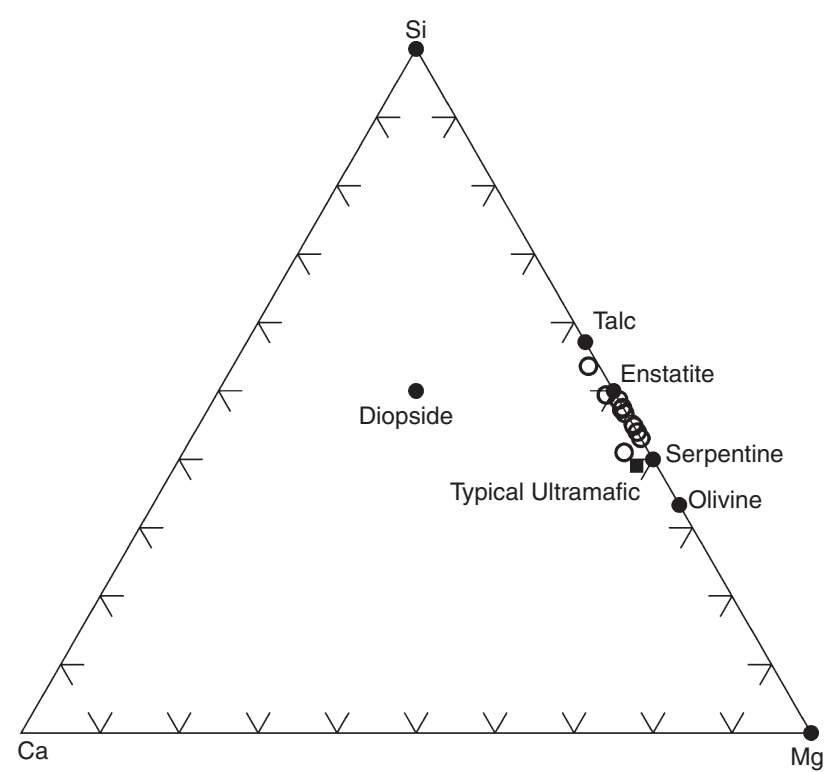

Fig. 3. Ternary diagram detailing the chemography of Cherry Hill serpentinites (open circles) projected onto the plane $\mathrm{CaO}-\mathrm{MgO}-\mathrm{SiO}_{2}$, also showing typical ultramafic rock (filled square) and mineral compositions (solid circles). edaphic characteristics, including soil depth $28.9 \quad 2.0(\mathrm{~cm}), \mathrm{pH}$ 5.40 .1 , bulk density $0.880 .07\left(\mathrm{~g} / \mathrm{m}^{3}\right)$, soil organic matter

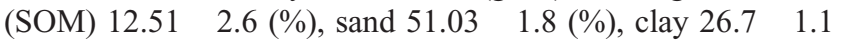
(\%) and $\mathrm{C}: \mathrm{N} 15.18 \quad 0.9$.

Soil moisture and soil depth increased with distance from the barrens areas. Strong positive correlation with distance was found for both soil moisture and depth $(r=0.570, P<0.001$ and $r=0.848, P<0.001$ ), respectively (Fig. 4). Other soil physiochemical parameters, such as texture and trace element content, did not show correlations with distance $(P>0.05$, Spearman's rank correlation).

Magnesium concentrations were high and corresponding $\mathrm{Ca}: \mathrm{Mg}$ ratios low $(<0.5)$ across all sites. The $\mathrm{Ca}: \mathrm{Mg}$ ratio is a measure of serpentine cation imbalance. Surface soils had higher $\mathrm{Ca}: \mathrm{Mg}(0.2$ to 0.5$)$ ratios than did subsurface soils (0.05 to 0.2 ). Chromium and $\mathrm{Ni}$ concentrations were elevated with a maximum of over $6000 \mathrm{ppm}$ and $2700 \mathrm{ppm}$, respectively.

The $\mathrm{pH}$ of the soils was typically acidic (surface soils average $\sim 5.4$ ), but ranged from $(\sim 4-7)$. Soil $\mathrm{pH}$ was negatively correlated with $\mathrm{Ca}: \mathrm{Mg}(r=-0.49, P<0.05)$ and $\mathrm{C}: \mathrm{N}$ ratios $(r=-0.62$, $P<0.05$ ). SOM content (based on LOI) had a mean of $16.6 \%$ in the upper $5 \mathrm{~cm}$, declining to below 7\% with depth $(10-15 \mathrm{~cm})$. $\mathrm{N}$ content was generally low and $\mathrm{C}: \mathrm{N}$ ratios varied between 5 and 24, with the higher values on the more developed soils. Depth profiles of SOM displayed increasing $\delta^{13} \mathrm{C}$ isotopic signatures from 2 means of $-26.23 \%$ o $(0-5 \mathrm{~cm})$ to $-20.95 \%$ o $(10-15 \mathrm{~cm})$ (Table 2), whereas remnant grassland areas recorded mean $\delta^{13} \mathrm{C}$ isotopic signatures of $-16.23 \%$ o $(0-5 \mathrm{~cm})$.

\section{Woody-species characteristics}

Using high-resolution Google Earth imagery, the current (2013) percentage of the site that contains grassland or savanna is less than $2 \%$. The forests include xeric woodlands, with stands of $P$. virginiana and J. virginiana intermingled with Quercus marilandica Meunch (blackjack oak) and Quercus stellata

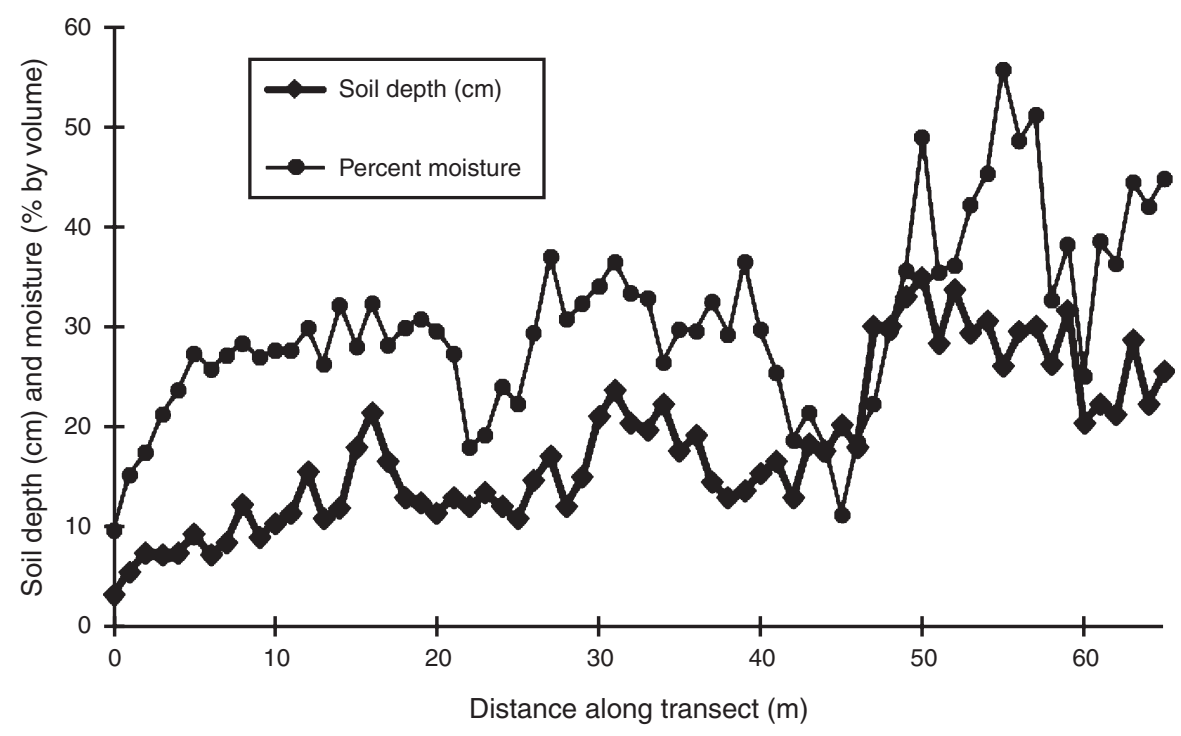

Fig. 4. Monotonic change of variables along transects. The relationship between soil depth, percentage moisture (volume) and distance from barrens bedrock were assessed using correlational analysis $(P<0.0001)$. Data are compiled averages of four transects from rocky barrens to woodland-forest ecotone. The correlation of the two variables soil depth and moisture is significant $(r=0.67, P<0.001)$. 
Wang (post oak) as well as more mesophytic species. Large, open-crown trees are rare; more typical are contorted downsweeping branches of $Q$. marilandica surrounded by standgrown trees. Aerial photographs from 1937 show conifers advancing from the dendritic drainage areas. Mesophytic forests are composed of these oaks and others such as Quercus rubra L. (red oak), Q. alba L. (white oak), Q. montana Willd (chestnut oak) and $Q$. velutina Lam (black oak), along with numerous other species most notably Prunus spp. (black cherry, wild cherry), Pinus spp. (e.g. white pine, shortleaf pine), Fagus grandifolia Ehrh (American beech), Acer rubrum L. (red maple), Sassafras albidum Nutt (sassafras), Populus grandidentata Michx. (bigtooth aspen), Nyssa sylvatica Marshall (blackgum), Betula lenta L (sSweet birch) and Robinia pseudoacacia L. (black locust). On exposed rock surfaces, the serpentine endemic (as reviewed by Harris and Rajakaruna 2009) Cerastium velutinum var. velutinum Raf (serpentine mouse eared chickweed) and other serpentinophiles, such as Symphyotrichum depauperatum Fern (serpentine aster), and saplings of $Q$. marilandica, are common.

Biodiversity richness estimators Chao 1, Chao 2 and ACE estimated maximum woody-species richness between 26.3 and 30.8 species. The observed richness was 24 species (Table 3). Overall diversity and mean diversity for the 32 sites were calculated as $2.74(\bar{X}=1.67 ; s=0.29)$ (Shannon index) and

Table 2. Descriptive statistics for soil $\delta^{13} \mathrm{C}(\%)$ and soil organic matter in grassland and woodland elements

Means followed by the same letter are not significantly different (ANOVA, post hoc Tukey's HSD, $P=0.05$ )

\begin{tabular}{lccccc}
\hline Statistic & Grassland & $\begin{array}{c}\text { Forest } \\
(0-5 \mathrm{~cm})\end{array}$ & $\begin{array}{c}\text { Forest } \\
(5-10 \mathrm{~cm})\end{array}$ & $\begin{array}{c}\text { Forest } \\
(5-15 \mathrm{~cm})\end{array}$ & $\begin{array}{c}\text { Forest } \\
(10-15 \mathrm{~cm})\end{array}$ \\
\hline Mean & $-16.23 \mathrm{a}$ & $-26.23 \mathrm{~b}$ & $-23.59 \mathrm{bcd}$ & $-22.98 \mathrm{de}$ & $-20.95 \mathrm{e}$ \\
Minimum & -17.91 & -29.23 & -27.25 & -26.49 & -25.14 \\
Maximum & -14.23 & -19.28 & -18.11 & -19.72 & -16.54 \\
s.e. & 0.68 & 0.44 & 0.67 & 0.65 & 0.60 \\
\hline
\end{tabular}

$0.92(\bar{X}=0.78 ; s=0.08)$ (Simpson index). On the basis of relative IV, the most important species were $P$. virginiana and $J$. virginiana (Table 3 ). These two species had similar relative IVs and stood out from all other species. A second group of species included $A$. rubrum and $Q$. marilandica. At the genus level, Quercus was the most important contributor to the tree community, with $39 \%$ relative IV. On the basis of basal area, the most dominant species were $Q$. rubra, $P$. virginiana and Q. marilandica. Constancy values (Table 3) showed A. rubrum (0.78) as a clear break from the next grouping of species ( $P$. virginiana and $J$. virginiana), whose constancy values hovered near 0.5 , followed by $Q$. marilandica, $F$. grandifolia, $N$. sylvatica and $Q$. stellate, with constancy values near 0.4 .

The Mantel test comparing floristic similarity and environmental distance showed significant $(P<0.05)$ correlations between environmental distance and ecological distance for the following parameters: heat load, bulk density, basal area, diversity $(\mathrm{H})$, percentage sand; $\mathrm{Ni}$ and $\mathrm{Cr}$ (Table 4). The ANOSIM statistic was calculated only for the canopy category (woodland/forest), with a resulting $r=0.14$ and $P$-value of 0.05 . Both the Mantel and ANOSIM tests yielded significant $(P<0.05)$ but weak correlations.

\section{Relationships between vegetation and abiotic properties}

Results of multiple regression analysis were evaluated to understand the response of species distributions to soil properties. Table 5 shows the regression results for the eight species the importance of which met or exceeded $5 \%$, with topographic and edaphic parameters as the predictor variables. Predictor variables that indicated a meaningful contribution to explaining species abundance were incident radiation and soil $\mathrm{Mg}$ content for $Q$. marilandica, incident radiation for $J$. virginiana and $Q$. stellata, soil organic carbon (SOC) for A. rubrum, soil depth for $F$. grandifolia and bulk density for the conifers.

PCA was performed for 16 abiotic parameters across the 32 sampled quadrats, so as to identify covariation between the solar radiation and soil variables (Fig. 5). The main trend of variation in

Table 3. Constancy, importance (average value of a species when present), density, dominance and importance value (average of relative density and relative dominance) measures for woody stems in serpentinite woodland at Cherry Hill, Maryland, USA

\begin{tabular}{|c|c|c|c|c|c|}
\hline Species & Constancy & Importance & $\begin{array}{l}\text { Dominance } \\
\left(\mathrm{m}^{2} \mathrm{ha}^{-1}\right)\end{array}$ & $\begin{array}{c}\text { Density } \\
\left(\text { stems ha }^{-1}\right)\end{array}$ & $\begin{array}{c}\text { Importance } \\
\text { value (IV) }(\%)\end{array}$ \\
\hline Acer rubrum L. & 0.78 & 1.09 & 57.99 & 77.78 & 9.88 \\
\hline Ailanthus altissima Mill. & 0.03 & 0.03 & 0.75 & 2.22 & 0.27 \\
\hline Betula lenta $\mathrm{L}$. & 0.06 & 0.06 & 3.46 & 4.44 & 0.60 \\
\hline Celtis occidentalis L. & 0.06 & 0.06 & 0.59 & 4.44 & 0.41 \\
\hline Cercis canadensis L. & 0.03 & 0.03 & 0.78 & 2.22 & 0.22 \\
\hline Cornus florida L. & 0.06 & 0.06 & 1.46 & 4.44 & 0.38 \\
\hline Diospyros virginiana L. & 0.03 & 0.03 & 1.85 & 2.22 & 0.24 \\
\hline Fagus grandifolia Ehrh. & 0.43 & 0.65 & 57.13 & 46.67 & 6.19 \\
\hline Juniperus virginiana L. & 0.50 & 1.06 & 86.57 & 75.56 & 12.14 \\
\hline Kalmia latifolia L. & 0.12 & 0.15 & 1.63 & 11.11 & 1.06 \\
\hline Liriodendron tulipifera L. & 0.09 & 0.09 & 23.72 & 6.67 & 108 \\
\hline Nyssa sylvatica Marsh. & 0.43 & 0.75 & 57.69 & 53.33 & 7.20 \\
\hline Pinus strobus L. & 0.03 & 0.03 & 6.92 & 2.22 & 0.90 \\
\hline Pinus virginiana Mill. & 0.56 & 0.78 & 164.98 & 55.56 & 13.43 \\
\hline Populus grandidentata Michx. & 0.03 & 0.06 & 6.40 & 4.44 & 0.58 \\
\hline Prunus serotina Ehrh. & 0.28 & 0.28 & 20.46 & 20.00 & 2.71 \\
\hline
\end{tabular}


the soil chemical properties and topographic variables, as reflected by the PCA Axis 1 (accounting for 30\% of variance), was one dominated by significant correlations of soil texture (\%sand and bulk density), soil depth, $\mathrm{Mg}, \mathrm{Cr}$ and $\mathrm{Ni}$ concentrations, incident radiation and heat load. The second trend of soil variation, as reflected by the PCA Axis 2 (17\% of variation), can be interpreted as a combined gradient of essential nutrients ( $\mathrm{C}$ and $\mathrm{N})$ and SOC. The PCA (axes accounting for $44 \%$ of the variation) revealed strong positive associations between both soil depth and bulk density, which were negatively correlated with heavy metal concentrations and $\mathrm{pH}$. Soil $\mathrm{Ca}: \mathrm{Mg}$ ratios and $\mathrm{Al}$ concentrations were negatively correlated with macronutrients $(\mathrm{C}, \mathrm{N}, \mathrm{P})$ and SOC. Fig. $5 b$ shows the PCA factor map for the abiotic variables and the biotic covariates for the sampling plots. When the characteristics of woody-species community are included in the PCA, both basal area and stem density are positively correlated with soil $\mathrm{Ca}: \mathrm{Mg}$ ratios and $\mathrm{Al}$ content. Diversity (Shannon's index) was strongly correlated with soil depth and bulk density, and negatively related to heavy metal concentrations

Table 4. Effects of environmental distance on similarity between plots Mantel statistic calculated by comparing matrix of environmental distance with Bray-Curtis distance. The standardised Mantel statistic $(r)$ indicates the strength of the relationship between sample-point position and forestfloor thickness, and the associated $P$-value indicates the significance of that relationship

\begin{tabular}{lcc}
\hline Environmental indicator & Correlation coefficient $(r)$ & $P$-value \\
\hline Heat load & 0.126 & 0.009 \\
Bulk density & 0.236 & 0.003 \\
Basal area & 0.141 & 0.015 \\
Diversity (H) & 0.109 & 0.034 \\
Percentage sand & 0.203 & 0.002 \\
Nickel & 0.111 & 0.034 \\
Chromium & 0.159 & 0.009 \\
Canopy & 0.150 & 0.009 \\
\hline
\end{tabular}

and heat load. As individual-species basal area, stem density and diversity typically respond to environmental gradients, constrained ordination utilising RDA was used to infer relationships between the species matrix and the environmental matrix, using Euclidean distance between sites. Arrows of increasing species abundance represent RDA scores. The sum of the RDA eigenvalues for the first two axes using all abiotic explanatory variables accounted for $36.8 \%$ of the woodyspecies composition. After reduced variable selection based on ANOVA tests of the ordination model, seven terms were selected, and these collectively explained $27.1 \%$ of the variance (Fig. 6). Interestingly, those species whose importance was $>4 \%$ are partitioned into the four quadrants of the ordination. From the RDA Axes 1 and 2 biplot, it can be seen that traditional serpentinesavanna (shade-intolerant) woody species (S. albidum, Q. stellata and $Q$. marilandica) are positively associated with increasing incident radiation and negatively associated with increasing soil depth, $\mathrm{Al}$ and $\mathrm{Mg}$ soil concentrations. Post-disturbance, initial colonisers ( $J$. virginiana and $P$. virginiana) are strongly negatively correlated with bulk density. Q. alba and Q. montana, which are widely distributed across a variety of conditions from wet mesic to subxeric, are associated with increasing bulk density. Shade-tolerant species such as N. sylvatica, $A$. rubrum and $F$. grandifolia are correlated with increasing soil depth and soils with more $\mathrm{Ca}$ and $\mathrm{Al}$.

Soils at the site differed in the total amount, vertical distribution and isotopic composition of SOM (Tables 1, 2). ANOVA results indicated significant differences in the isotopic means according to their depth $\left(F_{4,87}=27.6\right.$, $P \quad 0.0001)$. Tukey's HSD test showed that the mean $\delta^{13} \mathrm{C}$ of grassland soils $\left(\begin{array}{ll}-16.2 & 0.7 \%\end{array}\right)$ was significantly higher than that of shallow forested soils $\left(\begin{array}{ll}-26.2 & 0.4 \% \text { o }\end{array}\right)$ (Table 5). Shallow forested soils were significantly different from deeper soils (-20.95 $0.6 \%$ ). Total soil $\mathrm{C}$ and $\mathrm{N}$ and soil $\mathrm{C}: \mathrm{N}$ declined with soil depth. $\mathrm{C}: \mathrm{N}$ ratios were significantly different for all depths, ranging from 15.180 .88 on the surface soils to 11.621 in soils $10-15 \mathrm{~cm}$ below surface $\left(F_{2,66}=5.9\right.$,

Table 5. Results of multiple regression, with list of factors significantly contributing to species abundance SOC, soil organic carbon. ${ }^{* * *} P<0.001 ; * * P<0.01 ; * P<0.05$; ' ', $P<0.1$

\begin{tabular}{|c|c|c|c|c|c|c|c|c|c|c|}
\hline & P.virginiana & J. virginiana & A. rubrum & Q. marilandica & Q. rubra & N. sylvatica & Q. alba & Q. stellata & F. grandifolia & Q. montana \\
\hline IV (\%) & 13.43 & 12.14 & 9.88 & 9.40 & 8.10 & 7.20 & 7.03 & 6.26 & 6.19 & 4.40 \\
\hline Incident radiation & 0.9247 & $0.0249 *$ & 0.1791 & $0.0008 * * *$ & 0.4332 & 0.2136 & 0.9123 & $0.0450 *$ & 0.3030 & 0.3225 \\
\hline Heat load & 0.2516 & 0.4869 & 0.3661 & 0.8494 & 0.9552 & 0.9203 & 0.9825 & 0.2522 & 0.1128 & 0.3502 \\
\hline Soil depth & 0.2599 & 0.3110 & 0.8937 & $0.0463 *$ & 0.1881 & 0.3041 & 0.3381 & 0.1689 & $0.0242 *$ & 0.9920 \\
\hline Bulk density & $0.0023 * *$ & $0.0037 * *$ & 0.8260 & 0.8860 & 0.5216 & 0.2157 & $0.0415^{*}$ & 0.2686 & 0.9894 & 0.1171 \\
\hline Texture $(\%$ sand $)$ & 0.0976 & 0.2800 & 0.2942 & 0.6247 & 0.8124 & 0.9313 & 0.3207 & 0.3451 & 0.1454 & 0.6054 \\
\hline Calcium : magnesium & 0.9840 & 0.2962 & 0.7824 & 0.7031 & 0.9971 & 0.4587 & 0.7945 & 0.5441 & 0.6414 & 0.3639 \\
\hline Magnesium & 0.6146 & 0.5570 & 0.5725 & $0.0019 * *$ & 0.1500 & 0.6177 & 0.0914 & 0.3238 & 0.7491 & 0.3623 \\
\hline Aluminium & 0.7988 & 0.7323 & 0.1491 & 0.9176 & 0.0673 & 0.0583 & 0.8508 & 0.4152 & 0.5380 & 0.8685 \\
\hline Chromium & 0.5879 & 0.2397 & 0.2066 & 0.1012 & 0.6214 & 0.9977 & 0.6126 & 0.3991 & 0.6870 & $0.0434 *$ \\
\hline Nickel & 0.8699 & 0.2237 & 0.7478 & 0.3211 & 0.8340 & 0.6190 & 0.9519 & 0.5875 & 0.6307 & 0.1074 \\
\hline Phosphorus & 0.5192 & 0.5066 & 0.7822 & 0.9800 & 0.7523 & 0.6641 & 0.4927 & 0.9619 & 0.9430 & 0.2268 \\
\hline $\mathrm{SOC}$ & 0.6435 & 0.1185 & $0.0298 *$ & $0.0053 * *$ & 0.9782 & 0.2790 & 0.5185 & 0.2333 & 0.8701 & 0.7036 \\
\hline Carbon: nitrogen & 0.5806 & 0.2325 & 0.6793 & 0.8013 & 0.5674 & 0.6443 & 0.1727 & 0.1105 & 0.8015 & 0.6972 \\
\hline Carbon & 0.7737 & 0.7963 & 0.2099 & 0.1231 & 0.4380 & 0.8148 & 0.4280 & 0.4885 & 0.7995 & 0.5145 \\
\hline Nitrogen & 0.7506 & 0.9537 & 0.1179 & 0.3581 & 0.6363 & 0.5329 & 0.3124 & 0.7375 & $0.0153 *$ & 0.5744 \\
\hline $\mathrm{pH}$ & 0.7946 & 0.1863 & 0.5144 & 0.1547 & $0.0176^{*}$ & 0.4256 & 0.2597 & 0.6743 & 0.1299 & 0.9047 \\
\hline Multiple $R^{2}$ & 0.59 & 0.68 & 0.57 & 0.79 & 0.57 & 0.46 & 0.51 & 0.55 & 0.62 & 0.56 \\
\hline
\end{tabular}


(a)

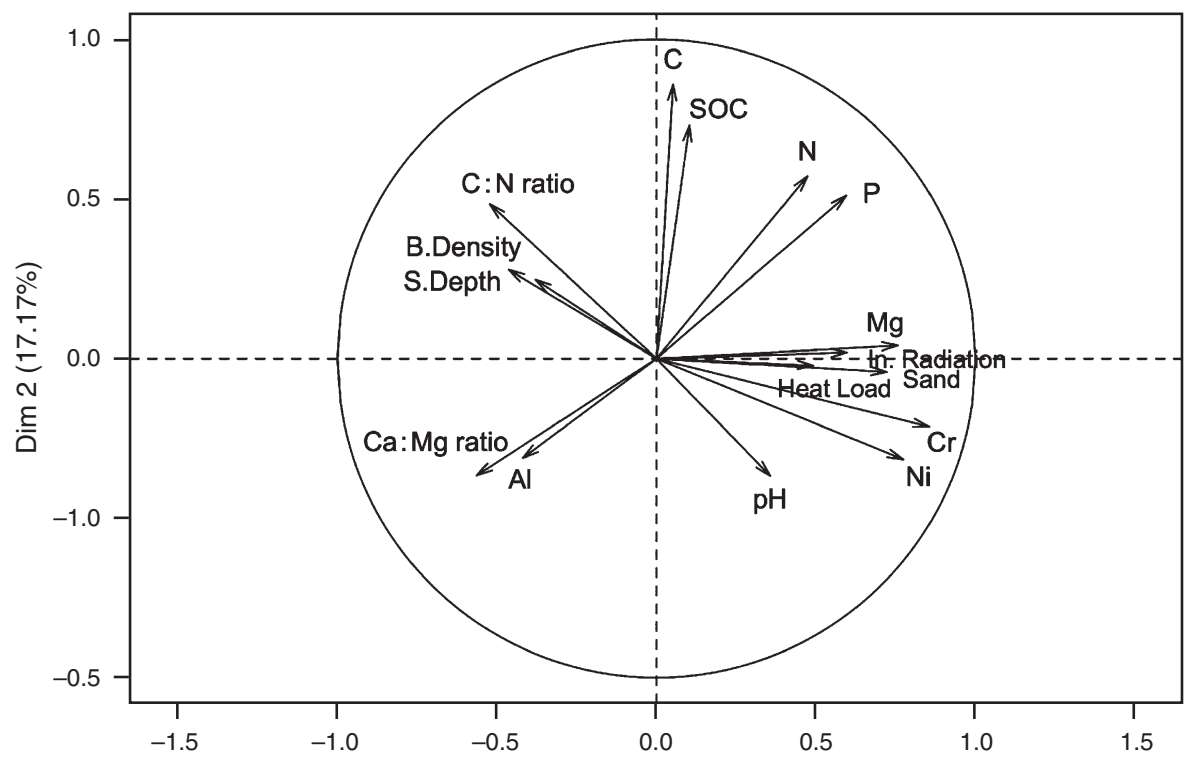

(b)

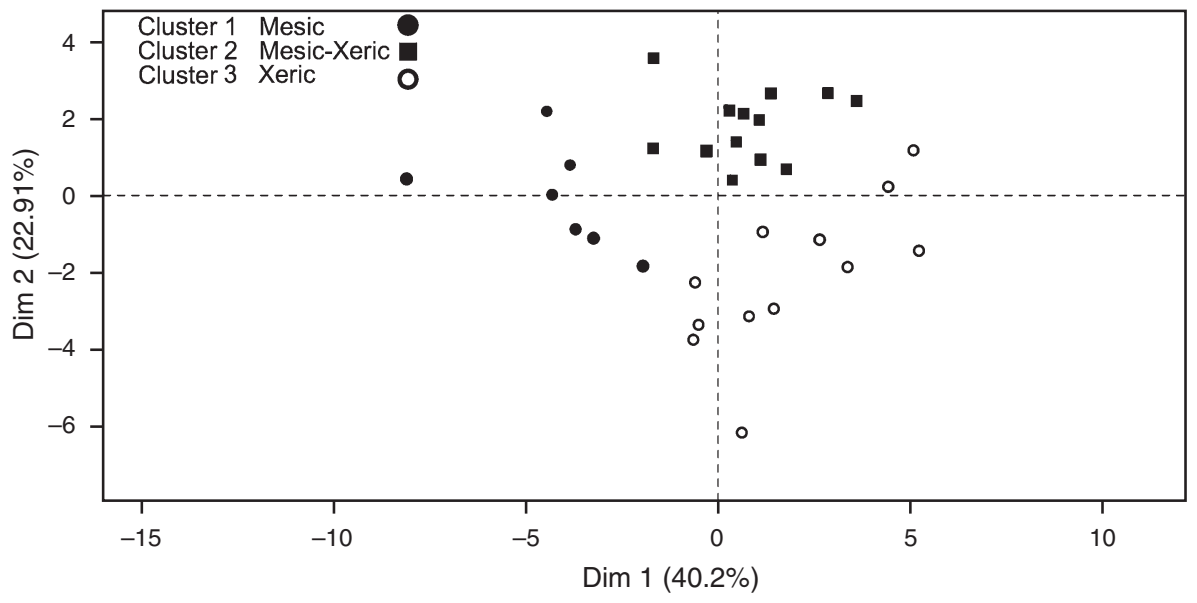

Fig. 5. (a) Unconstrained principal component analysis (PCA) correlation circle of pedological, topological and community variables. (b) Forest community clustering along an edaphic gradient.

$P=0.004)$. There were significant vegetation, depth and vegetation depth effects on $\delta^{13} \mathrm{C}$ of SOM (Table 5, Fig. 7).

\section{Age structure}

In total, 163 core samples were evaluated, with results displayed in the stand-age structure plot (Fig. 8). Skeleton plot chronologies varied among species. Older minimum age at breast height was generally seen in $Q$. stellata (114 15 years) and $Q$. marilandica (110 7 years) and the younger chronologies developed in species such as $A$. rubrum (53 4 years), F. grandifolia (56 8 years) and L. tulipifera (43 8 years). Only xeric oaks were present in the oldest age classes. The period before 1900 is composed of $54 \%$ xeric oaks and when all oaks are grouped they comprise $79 \%$ of trees from that era, although $Q$. montana is absent from this group (oldest minimum age is 88 years). The oldest non-oak was $N$. sylvatica (144 years). The period between
1900 and 1940 records a marked increase in conifers and concomitant decrease of xeric oaks, comprising $39 \%$ and $19 \%$ of all species, respectively. Between 1950 and 1990, the percentage of xeric oaks decreased to $3 \%$ and conifers to $13 \%$, whereas Acer spp. increased to $19 \%$. The number of shadetolerant species rose from $12.5 \%$ in the decades from 1850 to 1900 to $59 \%$ during the interval from 1950 to 1990 .

The age structure pooled from all the plots (Fig. 8) showed discontinuous patterns with prominent peaks of regeneration pulses and periods of either low or absent recruitment. Conifer establishment and recruitment clearly increased during 1900-1960, and then receded through the rest of the sampling period. There was a conspicuous absence of younger xeric oaks (post-1970s) and only two xeric oaks from 1950 to the present. At the same time, the percentage of non-oak deciduous trees increased to $68 \%$ post- 1950 . 


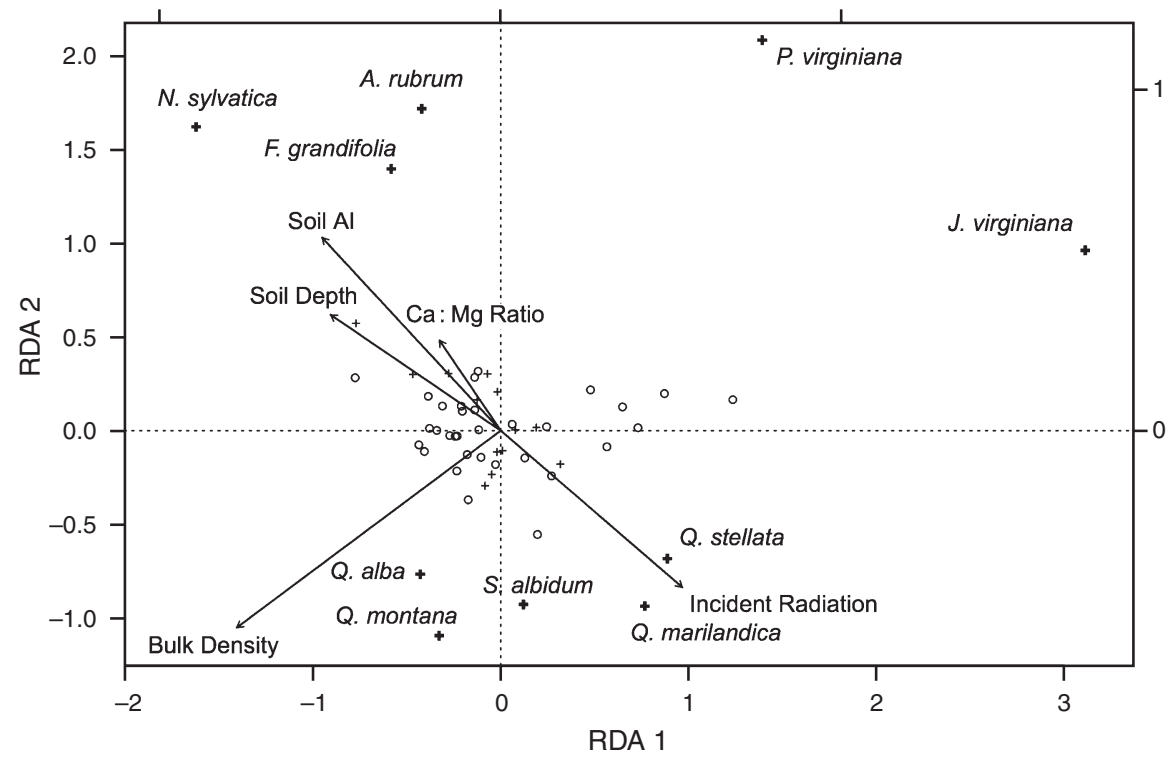

Fig. 6. Ordination diagram resulting from standard redundancy analysis (RDA) on transformed abiotic variables, illustrating relationships between woody species and physiochemical attributes. The diamonds represent species and the vectors indicate the strength of relationship.

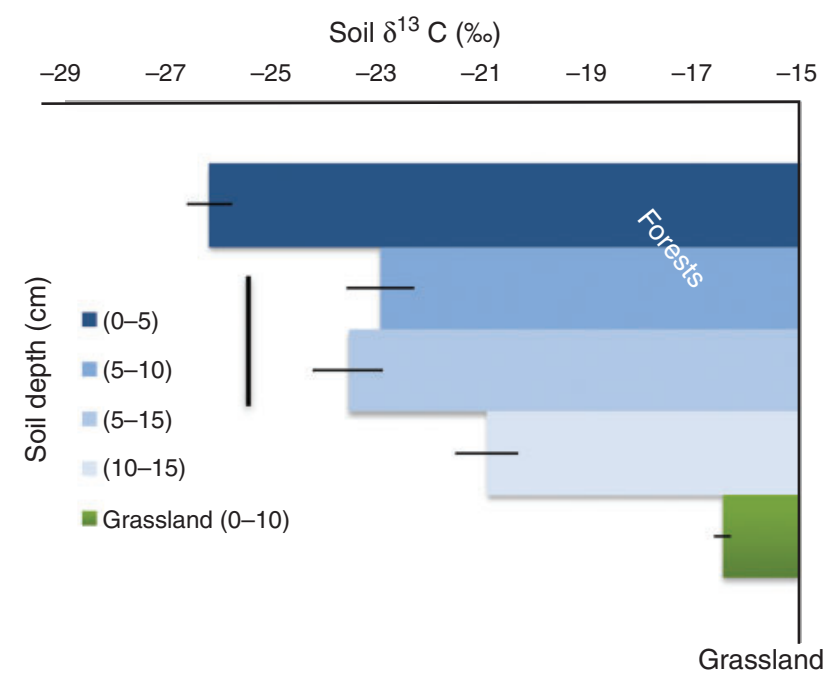

Fig. 7. Mean carbon isotopic signature in forest $(n=96)$ and grassland $(n=8)$ soils for Cherry Hill, Maryland, USA. Error bars are 1 s.e. Data interpreted as evidence for expansive $\mathrm{C}_{4}$ or $\mathrm{C}_{3}$ historic grassland. Vertical lines over 5-10- and 5-15-cm data indicate group pairs that were not significantly different using Tukey's HSD multiple comparisons.

\section{Discussion}

The present study examined a moderately sized area in the MidAtlantic but the changes - encroachment and mesophication represent potential widespread conservation problems. The serpentinite landscapes were once common components of the ancient Piedmont (Carroll et al. 2002; Owen 2002; Noss 2013). These unique plant communities have existed as persistent 'islands' embedded in a deciduous forest region for centuries or longer. We documented a state transition from grassland and xeric oak savanna to conifer-dominated communities that have given way to eastern broadleaf forests. Comparisons among geologic, pedologic and vegetation properties reflect this change and indicate that the conversion to forest has been rapid and characterised by large changes in soil properties $(\mathrm{pH}$, waterholding capacity, SOM composition) as well as plant-community structure (physiognomy and stem density) and composition (xeric to more mesic communities).

Thin-section and petrologic data confirmed that the geologic substrate is a serpentinised peridotite with characteristics typical of serpentinite terranes in the Appalachians (Misra and Keller 1978; Mittwede and Stoddard 1989; Gates 1992; Alexander 2009). Although $\mathrm{Ca}$ is depleted in bulk rock samples because of the breakdown of augite and interstitial plagioclase, soil $\mathrm{Ca}: \mathrm{Mg}$ ratios are higher in surface soils. The concentrations of SOC, $\mathrm{C}: \mathrm{N}$ and macronutrients in woodland and forested areas are linked to the turnover of organic matter and not the parent material.

Compared with the rock, soils are enriched in most trace metals, although the $\mathrm{Cr}$ contents were similar. This was likely to be due to resistance of Cr-oxides to weathering and suggests that these phases were not likely sources for $\mathrm{Cr}$ in soil solutions and plants of serpentine soils (Oze et al. 2004). Bedrock to forest transects demonstrated a strong correlation between soil moisture and soil depth. Soil nutrient content and soil moisture should be proportional to the cube of soil depth (Belcher et al. 1995), thus each of these parameters figured significantly in the PCA and RDA.

Afforestation has been relatively recent in this region (Tyndall 1992). Concomitant with the increase in tree density and size is the contraction of the grassland and savanna component study area from $18 \%$ in 1937 to $1.5 \%$ in 2013 , which is consistent with previous work documenting the invasion of serpentine savannas by conifers (Tyndall 1992; Barton and Wallenstein 1997; Arabas 2000).

In landscapes where $\mathrm{C}_{3}$ and $\mathrm{C}_{4}$ plants coexist, stable $\mathrm{C}$ isotopic composition of SOM represents a powerful method for 


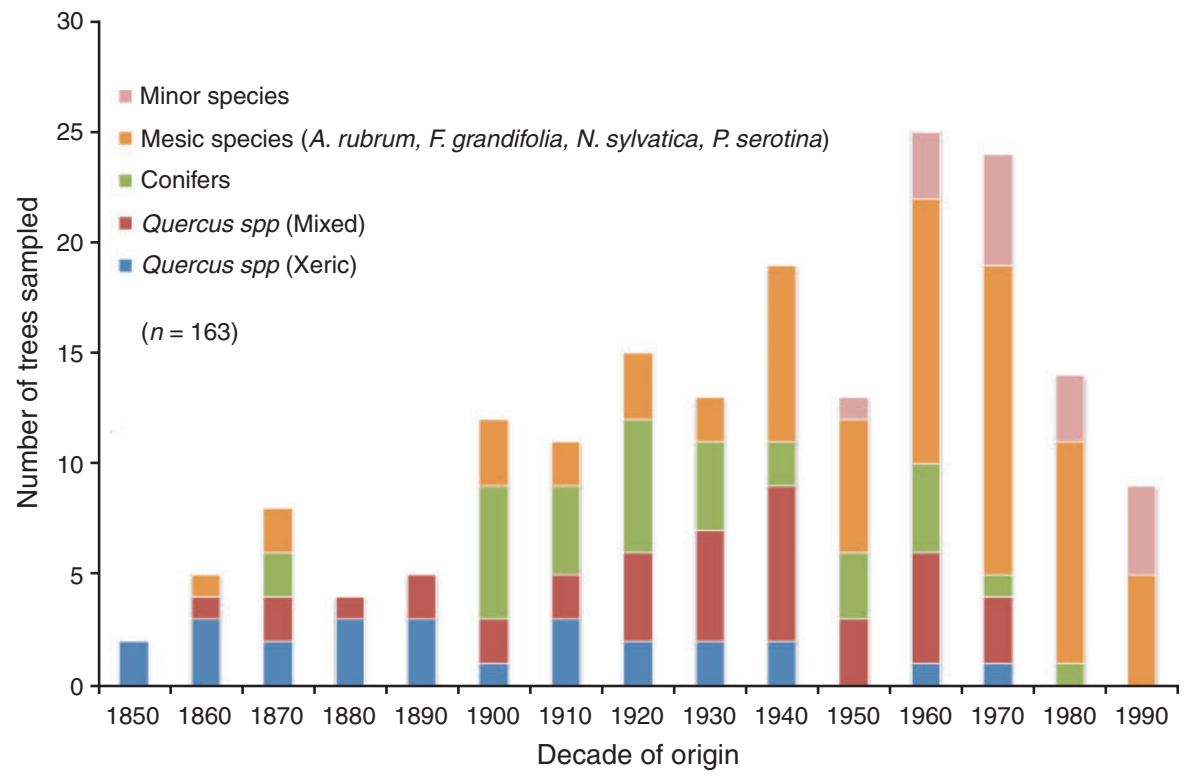

Fig. 8. Age distribution from trees on the basis of core data $(n=163)$. Xeric species are Quercus marilandica and $Q$. stellata. Mixed oak species include $Q$. alba, Q. montana, Q. rubra and Q. velutina.

reconstructing vegetation changes (Deines 1980; Tieszen and Archer 1990; Boutton and Yamasaki 1996; Boutton et al. 1998). Spatial patterns of soil $\delta^{13} \mathrm{C}$ were strongly related to type of vegetation (primarily woody versus grassland cover). Remnant grasslands are composed of a mixture of $\mathrm{C}_{3}$ grasses and forbs and $\mathrm{C}_{4}$ grasses. It is well documented that the $\delta^{13} \mathrm{C}$ signature of $\mathrm{C}_{3}$ plants (ranging from $26 \%$ o to $28 \%$ ) is easily distinguished from that of the $\mathrm{C}_{4}$ plants (ranging from $12 \%$ to $15 \%$ ) (DeNiro and Epstein 1977; Cerling et al. 1989; Tieszen 1991; Ehleringer et al. 2000; Fox et al. 2012; Throop et al. 2013). Other processes besides vegetation change alter isotopic ratios (such as preferential degradation of some plant materials, microbiological activity, Suess effect, and adsorption processes) and may cause shifts of the order of 1-3\%o (Friedli et al. 1987; Becker-Heidmann and Scharpenseel 1992; Trolier et al. 1996; Ehleringer et al. 2000; SantRuCkova et al. 2000; Krull et al. 2005). $\delta^{13} \mathrm{C}$ enrichment in temperate forest soils larger than 3-4\%o is generally attributed to the presence of remaining old $\mathrm{C}_{4}$-derived SOC. Following the reasoning of Wynn and Bird (2008), we sampled the upper soils (A horizon) and assumed that the intrinsic metabolic processes occurring in $\mathrm{C}_{3}$ and $\mathrm{C}_{4}$ vegetation impart an unequivocal $\delta^{13} \mathrm{C}$ signature into the $\mathrm{SOM}$ and that these signatures persist in decaying organic matter, such that increasing depth yields a chronologic sequence recording vegetation change. At the study area, $\delta^{13} \mathrm{C}$ values of soils in the grassland matrix averaged $-16 \%$ (Table 4), to $26 \%$ in forested areas dominated by $\mathrm{C}_{3}$ plants. Depth-integrated SOM $\delta^{13} \mathrm{C}$ significantly reflected the current vegetation cover (mixed $\mathrm{C}_{3}-\mathrm{C}_{4}$ and solely $\mathrm{C}_{3}$ ) and, accordingly, could be used as a reference to trace past changes in vegetation recorded in the SOM at deeper soil layers. The $\delta^{13} \mathrm{C}$ values of SOC consistently increased with depth, reflecting a higher percentage of $\mathrm{C}_{4}$-derived carbon in the older soils that is interpreted to reflect a site-wide shift in vegetation from $\mathrm{C}_{4}$ to $\mathrm{C}_{3}$ plants.
Multiple regression and ordination results supported the role of soil depth and incident radiation, both of which influence soil moisture content, as factors governing the occurrence of xeric serpentine savanna Quercus species. Abiotic factors in areas with higher importance of shade-tolerant species were associated with deeper soils, higher bulk density and higher $\mathrm{Ca}: \mathrm{Mg}$ ratios. In our site, early successional woodlands were favoured in areas of high incident radiation and broadleaf forests were more developed on slopes containing more clay rich and denser soils. Diversity of woody species was higher in areas with deeper soils. Unlike many systems with heavy metals, we found no correlations between toxic metals $(\mathrm{Cr}$ and $\mathrm{Ni}$ ) and vegetation dynamics.

Historical records show that oak savanna ecosystems were important components of the Mid-Atlantic landscape (Shreve et al. 1910). The lack of any oaks before the 1850 s suggests that they were likely harvested for fuel, posts or to support grazing. Farming of these serpentinite areas is not documented and is unlikely, given the inhospitable nature of the soil. Our study indicated that tree recruitment before the 20th century was mostly oaks, perhaps regenerating from root sprouts or propagules in the seed bank. Xeric oak recruitment decreased over time and no xeric oaks younger than 40 years established in the forested areas, although seedlings and saplings still exist in the remnant grassland/savannas. This failure to regenerate is likely to reflect the consequences of changing disturbance regimes such as fire-suppression (Nuzzo 1986; Abrams 1992, 2006; Peterson and Reich 2001), along with competition with invasive and mesic tree species (Nuzzo 1986). White-tailed deer and squirrel herbivory can reduce recruitment, especially in isolated systems such as these serpentinite landscapes (Shea and Stange 1998; Haas and Heske 2005). A turning point for community development appears to be $\sim 1900$, with the encroachment of Pinus virginiana and Juniperus virginiana. These conifer species have a variety of characteristics that can 
potentially alter ecosystem processes for decades as they mature and senesce. Both conifers are aggressive invaders because of rapid growth, high seed production, high seed-dispersal efficiency, tolerance of xeric conditions and opportunistic use of ECM mycorrhizae (Ormsbee et al. 1976; Holthuijzen and Sharik 1984, 1985; Briggs and Gibson 1992; Axmann and Knapp 1993; Thiet and Boerner 2007). Once established, these species can have a profound effect on soil properties as a result of accumulation of organic matter on the forest floor and the eventual decomposition of detritus, which leads to higher water-holding capacity and lowering of soil $\mathrm{pH}$. This positive feedback between soil depth and litter cover exerted by the conifers could promote succession towards non-serpentine conditions.

The initial serpentine edaphic signature acts as a filter preventing species that belong to the regional flora but lack the traits required to survive in such conditions to successfully colonise these habitats. By the 1970s, such filters appear to have diminished. Current site characteristics have shifted towards more mesic conditions, with changes in soil properties such as bulk density, soil depth, $\mathrm{pH}, \mathrm{SOM}$ and metals concentration. Over time, the community has changed from xeric (grassland or oak savanna) to one dominated by more mesic oaks and shade-tolerant Acer, Nyssa and Fagus species. The major onset of Acer establishment began in the 1940s. Unlike the Pinus and Juniperus establishment pulse, which proceeded in an open-canopy situation, Acer dominance likely proceeded under closed canopy and canopy gaps because it is shadetolerant. One may speculate that over the past 100-200 years, the landscape has been dominated by Quercus, with patches of Pinus and Juniperus that historically were present at low numbers because of disturbance (mining, fire, grazing, logging). Hilgartner et al. (2009) recorded evidence of the presence of Pinus virginiana from the early $1800 \mathrm{~s}$ in a serpentine barren site only $50 \mathrm{~km}$ distant. Over the past 60 years, Acer has become abundant where it, along with other species currently present (N. sylvatica, Cornus florida and Celtis occidentalis), would normally be considered an aberrant species in a hostile edaphic setting. Age and diameter structure indicated a shift away from Quercus and towards an A. rubrum-dominated landscape. This same species shift has been widely reported throughout the eastern deciduous forests of North America (Abrams 1998; Nowacki and Abrams 2008; McEwan et al. 2010).

In the context of serpentinite ecosystems, the influx of conifers nearly a century ago has acted as a landscape modulator (Shachak et al. 2008). The resulting build-up of SOM increases the waterholding capacity, and other resources such as ground-level radiation facilitate the influx of new species adapted to the altered conditions. As the difference between the mesic woodlands and the xeric patches decreases, the resource contrasts also decrease, leading to increasing community similarity. Different oak species can grow in a wide variety of light and moisture conditions. However, none of the traditional serpentine oak species is considered shade tolerant to the same degree as are Acer spp., Fagus grandifolia and Nyssa sylvatica. With progressive development of the soil and a dense-canopy closure, growth and germination of the traditional xeric oak species are likely to be suppressed, marking a shift from

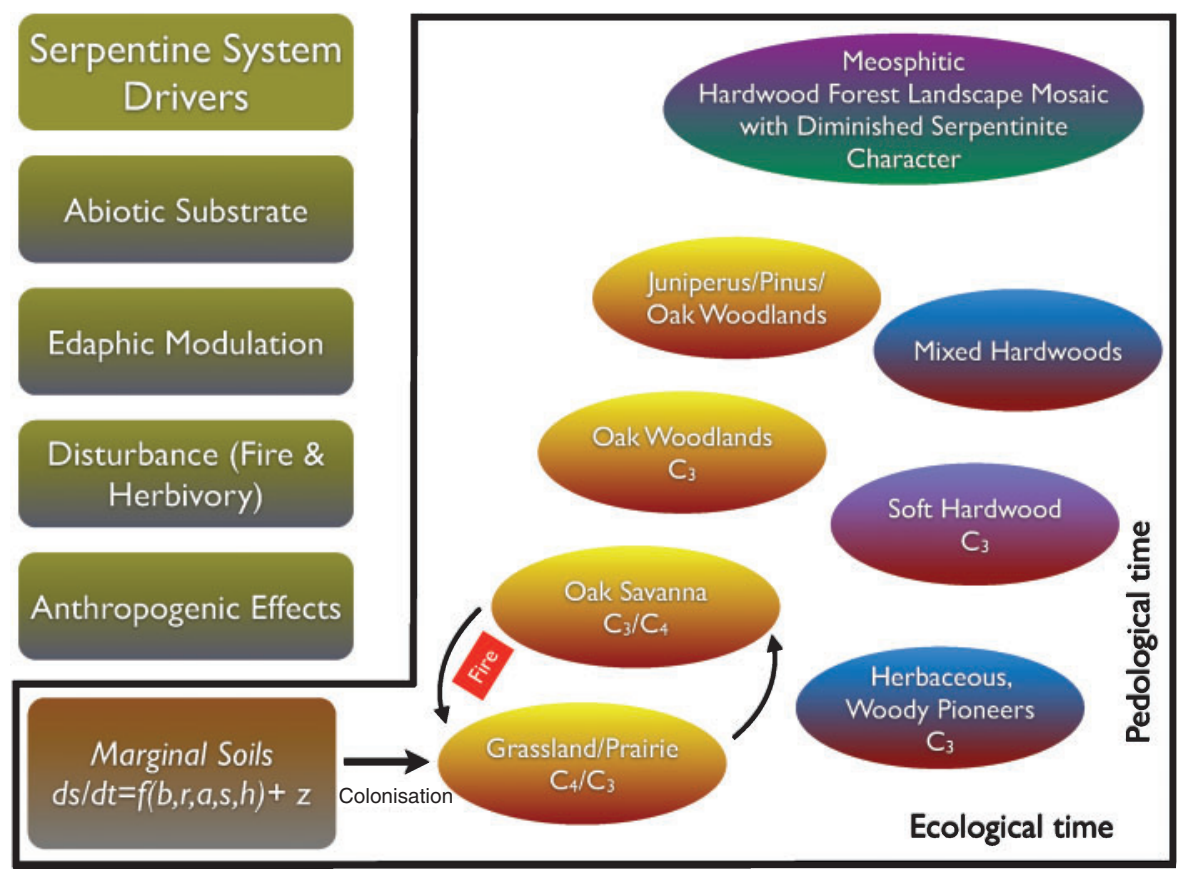

Fig. 9. Conceptual model for serpentine (orange-red colouring) habitats and species redistribution resulting in similar structure for a typical piedmont geoecologic system (blue/red colouring). Bedrock geology (specifically elemental concentrations and structures) exerts its control on soil fertility, with subtle variations resulting in markedly different above-ground and below-ground communities. The change in soils over time ( $d s / d t)$ equation from Huggett (1995) is a function of the various drivers, including $b$ (biology), $r$ (topography), $a$ (atmospheric effects), $s$ (soils) and $h$ (hydrology). Through changing vegetation dynamics, and species redistribution, the tree functional groups and forest types will see increasing similarity as a result of converging successional trajectories. Regional species pools, stochastic events and many other factors determine ultimate outcomes. 
xerothermic to mesic and/or nutrient-demanding species. Figure 9 details a conceptual model for pedologic and ecologic changes at serpentine sites of the Mid-Atlantic, with successional trajectories converging on a species redistribution and loss of typical serpentine species such as Cerastium arvense var. villosissimum, Andropogon gerardii and the xeric oaks (Q. marilandica and Q. stellata).

Although the canopy is still oak or pine dominated, the trajectory points to a maple-beech-red oak-dominated forest. The Mid-Atlantic has already lost much of its original grassland-oak woodland-forest mosaic. This state transition may lead to the loss of a unique ecosystem and, thus, taxonomic homogenisation with the regional flora. These changes result from anthropic influences, through changes in land use and fire frequency, the loss of Castanea dentata (American chestnut), and changing herbivore populations. Nearly a century ago these areas gave way to a mosaic of small woodlands typically characterised by xeric oaks interspersed with shallow rooting, low nutrient-tolerant conifers. Released from suppressive disturbance regimes (herbivory and fire, for example), Pinus virginiana and Juniperus virginiana quickly became the dominant species. However, our data suggest that the landscape is now undergoing another distinct change, as the once-open canopy structure has become more closed. Edaphic properties such as soil depth, chemistry and moisture that once drove community organisation across environmental stress gradients are now being modulated by species no longer filtered by the serpentine syndrome. This modulation may allow for the recruitment and establishment of drought-sensitive species beyond their typical tolerance limits (Warman and Moles 2008). This unique ecosystem, which took centuries to millennia to evolve, appears to be fading and may soon evanesce into the past.

\section{Sources of funding}

Our work was funded by the National Science Foundation (DEB-0423476 and DEB-1027188) and grants from the R. Balk and D. Elliott Field Fund (Johns Hopkins University).

\section{Conflicts of interest}

No conflicts of interest.

\section{Acknowledgements}

We thank Drs Richard Back, Naomi Levin, Bruce Marsh and Ben Passey for use of their elemental and isotopic facilities. We also thank Dr David Veblen and two anonymous reviewers for numerous constructive comments on the geology.

\section{References}

Abbe C (1898) A general report on the physiography of Maryland Johns Hopkins University. (Johns Hopkins University Press: Baltimore, MD) Abrams MD (1992) Fire and the development of oak forests. Bioscience 42, 346-353. doi:10.2307/1311781

Abrams MD (1998) The red maple paradox. Bioscience 48, 355-364. doi: $10.2307 / 1313374$

Abrams MD (2006) Ecological and ecophysiological attributes and responses to fire in eastern oak forests. In 'Fire in eastern oak forests: delivering science to landmanagers'. (Ed. MB Dickinson) pp. 74-89. (USDA Forest Service General Technical Report NRS-P-1)
Alexander EB (2009) Serpentine geoecology of the eastern and southeastern margins of North America. Northeastern Naturalist 16, 223-252. doi:10.1656/045.016.0518

Alexander EB, Ellis CC, Burke R (2007) A chronosequence of soils and vegetation on serpentine terraces in the Klamath Mountains, USA. Soil Science 172, 565-576. doi:10.1097/ss.0b013e31804fa22d

Arabas KB (2000) Spatial and temporal relationships among fire frequency, vegetation, and soil depth in an eastern North American serpentine barren. The Journal of the Torrey Botanical Society 127, 51-65. doi: $10.2307 / 3088747$

Archer S, Schimel DS, Holland EA (1995) Mechanisms of shrubland expansion: land use, climate or $\mathrm{CO}_{2}$ ? Climatic Change 29, 91-99. doi:10.1007/BF01091640

Axmann BD, Knapp AK (1993) Water relations of Juniperus virginiana and Andropogon gerardii in an unburned tallgrass prairie watershed. The Southwestern Naturalist 38, 325-330. doi:10.2307/3671610

Barton AM, Wallenstein MD (1997) Effects of invasion of Pinus virginiana on soil properties in serpentine barrens in southeastern Pennsylvania. The Journal of the Torrey Botanical Society 124, 297-305. doi:10.2307/2997264

Bazzaz FA (1968) Succession on abandoned fields in the Shawnee Hills, southern Illinois. Ecology 49, 924. doi:10.2307/1936544

Becker-Heidmann P, Scharpenseel H-W (1992) Studies of soil organic matter dynamics using natural carbon isotopes. The Science of the Total Environment 117-118, 305-312. doi:10.1016/0048-9697(92)90097-C

Belcher JW, Keddy PA, Twolan-Strutt L (1995) Root and shoot competition intensity along a soil depth gradient. Journal of Ecology 83, 673-682. doi: $10.2307 / 2261635$

Boutton TW, Archer SR, Midwood AJ, Zitzer SF, Bol R (1998) $\delta^{13}$ C values of soil organic carbon and their use in documenting vegetation change in a subtropical savanna ecosystem. Geoderma 82, 5-41. doi:10.1016/S0016-7061(97)00095-5

Bouyoucos GJ (1936) Directions for making mechanical analyses of soils by the hydrometer method. Soil Science 42, 225-230. doi:10.1097/00010694-193609000-00007

Briggs JM, Gibson DJ (1992) Effect of fire on tree spatial patterns in a tallgrass prairie landscape. Bulletin of the Torrey Botanical Club 119, 300-307. doi: $10.2307 / 2996761$

Brown ML, Brown RG (1984) 'Herbaceous plants of Maryland.' (University of Maryland: College Park, MD)

Burgess JL, Lev S, Swan CM, Szlavecz K (2009) Geologic and edaphic controls on a serpentine forest community. Northeastern Naturalist 16, 366-384. doi:10.1656/045.016.0527

Butaye J, Jacquemyn H, Honnay O, Hermy M (2002) The species pool concept applied to forests in a fragmented landscape: dispersal limitation versus habitat limitation. Journal of Vegetation Science 13, 27-34. doi:10.1111/j.1654-1103.2002.tb02020.x

Callaway RM, Davis FW (1993) Vegetation dynamics, fire, and the physicalenvironment in coastal central California Rid B-7010-2009. Ecology 74, 1567-1578. doi:10.2307/1940084

Carroll, W. D., Kapeluck, P. R., Harper, R. A., and Van Lear, D. H. (2002) Background paper: historical overview of the southern forest landscape and associated resources. In 'Southern forest resource assessment'. (Eds DN Wear, JG Greis) pp. 583-605. (U.S. Department of Agriculture, Forest Service, Southern Research Station: Asheville, NC)

Cerling TE, Quade J, Wang Y, Bowman JR (1989) Carbon isotopes in soils and palaeosols as ecology and palaeoecology indicators. Nature 341, 138-139. doi: $10.1038 / 341138 \mathrm{a} 0$

Chao A (1984) Nonparametric estimation of the number of classes in a population. Scandinavian Journal of Statistics 11, 265-270.

Chao A (1987) Estimating the population size for capture-recapture data with unequal catchability. Biometrics 43, 783-791. doi:10.2307/2531532

Chazdon RL, Colwell RK, Denslow JS, Guariguata MR (1998) Statistical methods for estimating species richness of woody regeneration in primary and secondary rain forests of Northeastern Costa Rica. In 'Forest 
biodiversity research, monitoring and modeling: conceptual background and old world case studies'. (Eds F Dallmeier, JA Comiskey) pp. 285-309. (Center for International Forestry Research: Paris)

Clements FE (1916) 'Plant succession: an analysis of the development of vegetation No. 242.' (Carnegie Institution of Washington: Washington, DC)

Cumming JR, Kelly CN (2007) Pinus virginiana invasion influences soils and arbuscular mycorrhizae of a serpentine grassland. The Journal of the Torrey Botanical Society 134, 63-73.

doi:10.3159/1095-5674(2007)134[63:PVIISA]2.0.CO;2

Curtis JT (1959) 'The vegetation of Wisconsin: an ordination of plant communities.' (University of Wisconsin Press: Madison, WI)

Deines P (1980) The carbon isotopic composition of diamonds: relationship to diamond shape, color, occurrence and vapor composition. Geochimica et Cosmochimica Acta 44, 943-961. doi:10.1016/0016-7037(80)90284-7

DeNiro MJ, Epstein S (1977) Mechanism of carbon isotope fractionation associated with lipid synthesis. Science 197, 261-263. doi:10.1126/science. 327543

Díaz S, Cabido M, Casanover F (1998) Plant functional traits and environmental filters at a regional scale. Journal of Vegetation Science 9, 113-122. doi:10.2307/3237229

Ehleringer JR, Buchmann N, Flanagan LB (2000) Carbon isotope ratios in belowground carbon cycle processes. Ecological Applications 10, 412-422. doi:10.1890/1051-0761(2000)010[0412:CIRIBC]2.0.CO;2

Fernandez-Going BM, Harrison SP, Anacker BL, Safford HD (2013) Climate interacts with soil to produce beta diversity in Californian plant communities. Ecology 94, 2007-2018. doi:10.1890/12-2011.1

Foster D, Swanson F, Aber J, Burke I, Brokaw N, Tilman D, Knapp A (2003) The importance of land-use legacies to ecology and conservation. Bioscience 53, 77-88. doi:10.1641/0006-3568(2003)053[0077:TIOLUL]2.0.CO;2

Fox DL, Honey JG, Martin RA, Pelaez-Campomanes P (2012) Pedogenic carbonate stable isotope record of environmental change during the Neogene in the southern Great Plains, southwest Kansas, USA: carbon isotopes and the evolution of C4-dominated grasslands. Geological Society of America Bulletin 124, 444-462. doi:10.1130/B30401.1

Friedli H, Siegenthaler U, Rauber D, Oeschger H (1987) Measurements of concentration, ${ }^{13} \mathrm{C} /{ }^{12} \mathrm{C}$ and ${ }^{18} \mathrm{O} /{ }^{16} \mathrm{O}$ ratios of tropospheric carbon dioxide over Switzerland. Tellus 39, 80.

doi:10.1111/j.1600-0889.1987.tb00272.x

Gates AE (1992) Domainal failure of serpentinite in shear zones, state-line mafic complex, Pennsylvania, USA. Journal of Structural Geology 14, 19-28. doi:10.1016/0191-8141(92)90141-I

Gleason HA (1926) The individualistic concept of the plant association. Bulletin of the Torrey Botanical Club 53, 7-26. doi:10.2307/2479933

Götzenberger L, de Bello F, Bråthen KA, Davison J, Dubuis A, Guisan A, Lepš J, Lindborg R, Moora M, Pärtel M (2012) Ecological assembly rules in plant communities - approaches, patterns and prospects. Biological Reviews of the Cambridge Philosophical Society 87, 111-127. doi:10.1111/j.1469-185X.2011.00187.x

Grime JP (1979) Primary strategies in plants. Transactions of the Botanical Society of Edinburgh 43, 151-160.

Haas JP, Heske EJ (2005) Experimental study of the effects of mammalian acorn predators on red oak acorn survival and germination. Journal of Mammalogy 86, 1015-1021. doi:10.1644/1545-1542(2005)86[1015:ESOTEO]2.0.CO;2

Harris T, Rajakaruna N (2009) Adiantum viridimontanum, Aspidotis densa, Minuartiamarcescens, and Symphyotrichum rhiannon: additional serpentine endemics from eastern North America. Northeastern Naturalist 16, 111-120. doi:10.1656/045.016.0509

Harrison SP, Rajakaruna N (2011) 'Serpentine: The evolution and ecology of a model system.' (University of California Press: Berkeley, CA)

Hilgartner WB, Nejako M, Casey R (2009) A 200-year paleoecological record of Pinus virginiana, trace metals, sedimentation, and mining disturbance in a Maryland serpentine barren 1. The Journal of the Torrey Botanical Society 136, 257-271. doi:10.3159/08-RA-088.1

Holthuijzen AM, Sharik TL (1984) Seed longevity and mechanisms of regeneration of eastern red cedar (Juniperus virginiana L.). Bulletin of the Torrey Botanical Club 111, 153-158. doi:10.2307/2996014

Holthuijzen AM, Sharik TL (1985) Colonization of abandoned pastures by eastern red cedar (Juniperus virginiana L.). Canadian Journal of Research 15, 1065-1068. doi:10.1139/x85-173

Huggett RJ (1995) ‘Geoecology: An Evaluation Approach.' (Routledge: New York, NY)

Huggett RJ (1998) Soil chronosequences, soil development, and soil evolution: a critical review. Catena 32, 155-172. doi:10.1016/S0341-8162(98)00053-8

Huston M (1979) A general hypothesis of species diversity. American Naturalist 113, 81-101. doi:10.1086/283366

Inouye RS, Huntly NJ, Tilman D, Tester JR, Stillwell M, Zinnel KC (1987) Old-field succession on a Minnesota sand plain. Ecology 68, 12-26. doi: $10.2307 / 1938801$

Jefferis WW (1880) Menaccanite and talc from Maryland. Proceedings of the Academy of Natural Sciences of Philadelphia 32, 292.

Jenny H (1941) 'Factors of soil formation: a system of quantitative pedology.' (McGraw-Hill Book Co: New York)

Jenny H (1980) 'The soil resource: Origin and behavior.' (Springer-Verlag: New York)

Johnson EA, Miyanishi K (2008) Testing the assumptions of chronosequences in succession. Ecology Letters 11, 419-431. doi:10.1111/j.1461-0248.2008.01173.x

Jones CC, del Moral RD (2009) Dispersal and establishment both limit colonization during primary succession on a glacier foreland. Plant Ecology 204, 217-230. doi:10.1007/s11258-009-9586-3

Keddy PA (1992) Assembly and response rules: two goals for predictive community ecology. Journal of Vegetation Science 3, 157-164. doi: $10.2307 / 3235676$

Keever C (1950) Causes of succession on old fields of the Piedmont, North Carolina. Ecological Monographs 20, 229-250. doi: $10.2307 / 1948582$

Kindt R, Coe R (2005) 'Tree diversity analysis: a manual and software for common statistical methods for ecological and biodiversity studies.' (World Agroforestry Centre (ICRAF): Nairobi, Kenya)

Kruckeberg AR (1984) 'California serpentines: flora, vegetation, geology, soils and management problems.' (University of California Press: Berkely, CA)

Krull ES, Skjemstad JO, Burrows WH, Bray SG, Wynn JG, Bol R, Spouncer L, Harms B (2005) Recent vegetation changes in central Queensland, Australia: evidence from $\mathrm{C}^{13} / \mathrm{C}^{14}$ analyses of soil organic matter. Geoderma 126, 241-259. doi:10.1016/j.geoderma.2004.09.012

Latham RE (1993) Global patterns of tree species richness in moist forests: energy-diversity theory does not account for variation in species richness. Oikos 67, 325-333. doi:10.2307/3545479

Lawton JH (1999) Are there general laws in ecology? Oikos 84, 177-192. doi: $10.2307 / 3546712$

Lorimer CG (1980) Age structure and disturbance history of a southern Appalachian virgin forest. Ecology 61, 1169-1184. doi:10.2307/1936836

Lortie CJ, Brooker RW, Choler P, Kikvidze Z, Michalet R, Pugnaire FI, Callaway RM (2004) Rethinking plant community theory. Oikos 107, 433-438. doi:10.1111/j.0030-1299.2004.13250.x

Ludwig JA, Reynolds JF (1988) 'Statistical ecology: a primer on methods and computing.' (J. Wiley \& Sons: New York)

Mantel N (1967) Ranking procedures for arbitrarily restricted observation. Biometrics 23, 65-78. doi: $10.2307 / 2528282$

Marye WB (1955a) The great Maryland barrens. I. Maryland Historical Magazine 50, 11-23.

Marye WB (1955b) The great Maryland barrens. II. Maryland Historical Magazine 50, 120-142. 
Marye WB (1955c) The great Maryland barrens. III. Maryland Historical Magazine 50, 234-253.

Maryland State Climatologist Office (2014) 'State Climatologists Report.' Maryland State Climatologist Office. Available at www.atmos.umd.edu/ climate. [Verified August 2014]

McCune B, Grace JB (2002) 'Analysis of ecological communities. 28.' (MjM Software Design: Gleneden Beach, OR)

McCune B, Keon D (2002) Equations for potential annual direct incident radiation and heat load. Journal of Vegetation Science 13, 603-606. doi:10.1111/j.1654-1103.2002.tb02087.x

McEwan RW, Dyer JM, Pederson N (2010) Multiple interacting ecosystem drivers: toward an encompassing hypothesis of oak forest dynamics across eastern North America. Ecography 34, 244-256. doi:10.1111/j.1600-0587.2010.06390.x

Misra KC, Keller FB (1978) Ultramafic bodies in the southern Appalachians; a review. American Journal of Science 278, 389-418. doi:10.2475/ajs.278.4.389

Mittwede SK, Stoddard EF (1989) 'Ultramafic rocks of the Appalachian Piedmont.' (Geological Society of America: Boulder, CO)

Muller PD, Candela PA, Wylie AG (1989) Liberty complex; polygenetic melange in the central Maryland Piedmont. 'Liberty complex; polygenetic melange in the central Maryland Piedmont'. (Eds JW Horton, N Rast) pp. 113-134. (Geological Society of America: Boulder, CO)

Noss RF (2013) Natural history of a forgotten American grassland. In 'Forgotten grasslands of the South'. pp. 1-32. (Island Press/Center for Resource Economics: Washington, DC)

Nowacki GJ, Abrams MD (2008) The demise of fire and 'mesophication' of forests in the eastern United States. Bioscience 58, 123. doi:10.1641/B580207

Nuzzo VA (1986) Extent and status of Midwest oak savanna: presettlement and 1985. Natural Areas Journal 6, 6-36.

Oosting HJ (1942) An ecological analysis of the plant communities of Piedmont, North Carolina. American Midland Naturalist 28, 1-126. doi: $10.2307 / 2420696$

Ormsbee P, Bazzaz FA, Boggess WR (1976) Physiological ecology of Juniperus virginiana in oldfields. Oecologia 23, 75-82. doi:10.1007/BF00351216

Owen W (2002) The history of native plant communities in the south. The southern forest resource assessment: technical report. US Forest Service general technical report SRS-53, pp. 47-62. (U.S.D.A. Forest Service Southern Research Station: Asheville, NC)

Oze C, Fendorf S, Bird DK (2004) Chromium geochemistry in serpentinized ultramafic rocks and serpentine soils from the Franciscan complex of California. American Journal of Science 304, 67-101. doi:10.2475/ajs.304.1.67

Peterson DW, Reich PB (2001) Prescribed fire in oak savanna: fire frequency effects on stand structure and dynamics. Ecological Applications 11, 914-927. doi:10.1890/1051-0761(2001)011[0914:PFIOSF]2.0.CO;2

Pickett ST, White PS (1985) 'The ecology of natural disturbance and patch dynamics.' (Academic Press: Orlando, FL)

Potts PJ (1987) 'A handbook of silicate rock analysis.' (Blackie and Sons: Glasgow)

Proctor J, Nagy L (1992) Ultramafic rocks and their vegetation: an overview. In 'The vegetation of ultramafic (serpentine) soils'. (Eds AJM Baker, J Proctor, RD Reeves) pp. 469-494. (Intercept: Andover, UK)

Rajakaruna N, Boyd RS (2009) Advances in serpentine geoecology: a retrospective. Northeastern Naturalist 16, 1-7. doi:10.1656/045.016.0501

Rajakaruna N, Harris TB, Alexander EB (2009) Serpentine geoecology of eastern North America: a review. Rhodora 111, 21-108. doi:10.3119/07-23.1

Robertson GP, Hutson MA, Evans FC, Tiedje JM (1988) Spatial variability in a successional plant community: patterns of nitrogen availability. Ecology 69, 1517-1524. doi:10.2307/1941649
SantRuCkova H, Bird MI, Lloyd J (2000) Microbial processes and carbonisotope fractionation in tropical and temperate grassland soils. Functional Ecology 14, 108-114. doi:10.1046/j.1365-2435.2000.00402.x

Shachak M, Boeken B, Groner E, Kadmon R, Lubin Y, Meron E, Ne'Eman G, Perevolotsky A, Shkedy Y, Ungar ED (2008) Woody species as landscape modulators and their effect on biodiversity patterns. Bioscience $\mathbf{5 8}$, 209-221. doi:10.1641/B580307

Shannon CE, Weaver W (1949) 'The mathematical theory of communication.' (University of Illinois Press: Urbana, IL)

Shea KL, Stange EE (1998) Effects of deer browsing, fabric mats, and tree shelters on Quercus rubra seedlings. Restoration Ecology 6, 29-34. doi:10.1046/j.1526-100x.1998.00614.x

Shreve F, Chrysler MA, Blodgett FH, Besley FW (1910) 'The plant life of Maryland.' Special publication, vol. III. (Johns Hopkins Press: Baltimore, MD)

Simpson EH (1949) Measurement of diversity. Nature 163, 688. doi:10.1038/163688a0

Smith RC, Barnes JH (2008) Geology of the Goat Hill serpentine barrens, Baltimore Mafic Complex, Pennsylvania. Journal of the Pennsylvania Academy of Science 82, 19-30.

Speer JH (2010) 'Fundamentals of tree-ring research.' (University of Arizona Press: Tuscan, AZ)

Stokes MA (1996) 'An introduction to tree-ring dating.'. (University of Arizona Press)

Stokes MA, Smiley TL (1968) 'An introduction to tree-ring dating.' (University of Chicago Press: Chicago, IL)

Thiet RK, Boerner REJ (2007) Spatial patterns of ectomycorrhizal fungal inoculum in arbuscular mycorrhizal barrens communities: implications for controlling invasion by Pinus virginiana. Mycorrhiza 17, 507-517. doi: $10.1007 / \mathrm{s} 00572-007-0123-8$

Throop HL, Lajtha K, Kramer M (2013) Density fractionation and ${ }^{13} \mathrm{C}$ reveal changes in soil carbon following woody encroachment in a desert ecosystem. Biogeochemistry 112, 409-422. doi:10.1007/s10533-012-9735-y

Tieszen LL (1991) Natural variations in the carbon isotope values of plants: implications for archaeology, ecology, and paleoecology. Journal of Archaeological Science 18, 227-248. doi:10.1016/0305-4403(91)90063-U

Tieszen LL, Archer S (1990) Isotopic assessment of vegetation changes in grassland and woodland systems. 'Isotopic assessment of vegetation changes in grassland and woodland systems'. (CB Osmond, LF Pitelka, GM Hidy) pp. 293-321. (Springer-Verlag: New York)

Tilman GD (1984) Plant dominance along an experimental nutrient gradient. Ecology 65, 1445-1453. doi:10.2307/1939125

Tilman D (1987) Secondary succession and the pattern of plant dominance along experimental nitrogen gradients. Ecological Monographs 57, 189-214. doi:10.2307/2937080

Trolier M, White JWC, Tans PP, Masarie KA, Gemery PA (1996) Monitoring the isotopic composition of atmospheric $\mathrm{CO}_{2}$ : measurements from the NOAA Global Air Sampling Network. Journal of Geophysical Research: Atmospheres (1984-2012) 101, 25897-25916.

Tyndall RW, Farr P (1989) Vegetation structure and flora of a serpentine pine-cedar savanna in Maryland. Castanea 54, 191-199.

Tyndall RW (1992) Historical considerations of conifer expansion in Maryland serpentine barrens. Castanea 57, 123-131.

Tyndall RW (2005) Twelve years of herbaceous vegetation change in oak savanna habitat on a Maryland serpentine barren after Virginia pine removal. Castanea 70, 287-297. doi:10.2179/0008-7475(2005)070[0287:TYOHVC]2.0.CO;2

Tyndall RW, Farr P (1990) Vegetation and flora of the pilot serpentine area in Maryland. Castanea 55, 259-265.

Van Auken OV (2000) Shrub invasions of North American semiarid grasslands. Annual Review of Ecology and Systematics 31, 197-215. doi:10.1146/annurev.ecolsys.31.1.197 
Van Auken OW (2009) Causes and consequences of woody plant encroachment into western North American grasslands. Journal of Environmental Management 90, 2931-2942. doi:10.1016/j.jenvman.2009.04.023

Walters RS, Yawney HW (2004) 'Silvics manual: vol. 2: hardwoods.' (United States Department of Agriculture: Washington, DC)

Warman L, Moles AT (2008) Alternative stable states in Australia's Wet Tropics: a theoretical framework for the field data and a field-case for the theory. Landscape Ecology 24, 1-13. doi:10.1007/s10980-008-9285-9

Weiher E, Keddy PA (1999) Relative abundance and evenness patterns along diversity and biomass gradients. Oikos 87, 355-361. doi: $10.2307 / 3546751$

White J (1979) The plant as a metapopulation. Annual Review of Ecology and Systematics 10, 109-145. doi:10.1146/annurev.es.10.110179.000545

Whittaker RH (1960) Vegetation of the Siskiyou Mountains, Oregon and California. Ecological Monographs 30, 279-338. doi:10.2307/1943563
Williams GH, Darton NH (1892) 'Geology of Baltimore and its vicinity: crystalline rocks.' (John Murphy and Company: Baltimore, MD)

Williams BM, Houseman GR (2013) Experimental evidence that soil heterogeneity enhances plant diversity during community assembly. Journal of Plant Ecology 7, 461-469.

Wright JP, Fridley JD (2010) Biogeographic synthesis of secondary succession rates in eastern North America. Journal of Biogeography 37, 1584-1596.

Wynn JG, Bird MI (2008) Environmental controls on the stable carbon isotopic composition of soil organic carbon: implications for modelling the distribution of $\mathrm{C}_{3}$ and $\mathrm{C}_{4}$ plants, Australia. Tellus. Series B, Chemical and Physical Meteorology 60, 604-621. doi:10.1111/j.1600-0889.2008.00361.x

Zavala MA, Espelta JM, Retana J (2000) Constraints and trade-offs in Mediterranean plant communities: the case of holm oak-Aleppo pine forests. Botanical Review 66, 119-149. doi:10.1007/BF02857785 